Article

\title{
High Resolution Characterization of Lithological Heterogeneity of the Paaratte Formation, Otway Basin (Australia), a Coastal to Shallow-Marine Deposit
}

\author{
Achyut Mishra ${ }^{1,2, *}$, Lukas Pajank ${ }^{1,2}$ and Ralf R. Haese ${ }^{1,2}$ \\ 1 Peter Cook Centre for CCS Research, School of Earth Sciences, The University of Melbourne, Victoria 3010, \\ Australia; lpajank@student.unimelb.edu.au (L.P.); ralf.haese@unimelb.edu.au (R.R.H.) \\ 2 CO2CRC Ltd., 11-15 Argyle Place South, Carlton, Victoria 3053, Australia \\ * Correspondence: achyutm@student.unimelb.edu.au
}

Received: 24 May 2019; Accepted: 21 June 2019; Published: 24 June 2019

\begin{abstract}
Coastal to shallow-marine deposits are inherently highly heterogeneous in sediment composition due to variable depositional conditions. Representation of heterogeneity at sub-seismic scales is required for understanding flow and geochemical processes and poses two challenges: Firstly, the representation of different rock types in geological models requires high resolution sampling vertically and laterally. Secondly, the heterogeneity in petrophysical, flow and mineralogical properties within each rock type needs to be sufficiently characterized in order to support (multiphase) flow and reactive transport simulations. This study addresses these challenges for the Paaratte Formation, Otway Basin (Australia), at the CO2CRC's Otway Research Facility to enable detailed simulations of $\mathrm{CO}_{2}$ flow and reactions. Based on the analysis of wireline logs, hyperspectral core logs and discrete samples from wells CRC-2 and CRC-3, five rock types are defined and characterized for two coastal to shallow-marine parasequences comprising four depositional facies. A combination of wireline logs is used to derive rock type logs for the wells CRC-2 and CRC-3 at $10 \mathrm{~cm}$ vertical resolution and allows high resolution cross-well correlation providing insights into the lateral extent of deposits. Findings of this study will inform future desktop and field studies at the CO2CRC's Otway Research Facility requiring information on sub-seismic lithological heterogeneity.
\end{abstract}

Keywords: rock typing; lithological heterogeneity; hyperspectral analysis; wireline logs

\section{Introduction}

Flow and reactive transport modelling have evolved to be an effective tool to reconstruct and predict the fluid flow and chemical evolution of a system [1]. To achieve meaningful results from such modelling studies, it is important to replicate realistic fluid flow paths in simulations. This is usually achieved by constructing static models and then using them as a basis in flow and reactive transport simulations. Various regional structural features are implemented in geostatic models followed by the population of flow and petrophysical properties using wireline and seismic data [2,3]. Such geostatic models often have dimensions of the order of kilometers. To computationally manage multiphase and coupled reactive transport simulation runs on such large scale, grid blocks with a vertical resolution of meters and a lateral resolution of tens of meters are implemented. While the use of geostatic models is helpful in replicating fluid flow paths based on field data, the limitation posed by large grid dimension persists. To further improve the results, it is important to implement sub-meter scale lithological heterogeneities in geostatic models [4,5]. Such high resolution lithological heterogeneity exists in the form of intercalated layers of fine and coarse sediments, cemented intervals and sedimentary structures such as cross, planar and massive bedding [6]. Any layers composed of low porosity-low permeability 
rock types are known as intraformational baffles, which occur within high porosity-high permeability reservoir rock [7]. Intraformational baffles can significantly affect fluid flow pathways as well as fluid-rock reactions due to their low porosity, low permeability, higher capillary entry pressures and relatively abundant reactive minerals such as clays [7-10]. The proportion of baffles in the reservoir can significantly alter the results from dynamic simulations [11]. Hence, it is critical to incorporate the properties of intraformational baffles in reservoir scale models in order to improve simulation results. This is not directly possible as the incorporation of intraformational baffles in reservoir scale models requires sub-meter scale grid sizes and, thereby, increases computational limitations. One possible way to accomplish this task is to study the processes at sub-meter scales and then upscale flow [12] and geochemical [13] responses in larger scale models. This allows lithological heterogeneity at sub-meter scale to be incorporated in reservoir scale models and should significantly improve the prediction of fluid plume migration and associated geochemical reactions.

The first important step towards implementing this approach is to define rock types based on lithological properties which are subsequently used to populate the geostatic models. The present study addresses this by developing a database of high resolution lithological properties in terms of rock type classes. Rock properties are analyzed on samples from the Paaratte Formation at the CO2CRC's Otway Research Facility site, which is a test and demonstration site for geological $\mathrm{CO}_{2}$ storage in the state of Victoria, Australia [14]. The Paaratte Formation is a sedimentary unit consisting of three units, the lowermost of which comprises three parasequences $[15,16]$. Lithological properties have been analyzed for the lower two parasequences of the deepest unit (Unit A), which spans over approximately 100 meters in thickness. The two parasequences of interest are composed of four depositional facies: distributary channel, proximal mouthbar, distal mouthbar and delta front [16]. Each of these facies lithological heterogeneity vertically at sub-meter scale [17-19]. Rock properties used in this study to characterize the rock types are: porosity, permeability, capillary entry pressure, mineral composition and grain size distribution.

Porosity, permeability and capillary entry pressure have been measured on discrete cores and wireline logs and the data is published for the two wells in the study area, CRC-2 and CRC-3 [19-22]. Continuous semi-quantitative mineral composition was measured on 104-meters of core from CRC-3 using hyperspectral core logging as part of the current study. Quantitative mineral composition and mineral specific grain sizes were also analyzed on 30 discrete samples from CRC-3 using QEMSCAN analysis.

The aforementioned properties have been used to define five distinct rock type classes: coarse sandstone, fine sandstone, siltstone, mudstone and carbonate-cemented sandstone. The classification of rock type classes is geologically reasonable as it is based on the relationship of lithological properties and depositional environments in the Paaratte parasequences.

The rock type classes need to be spatially mapped in order to support dynamic simulations. For this purpose, a continuous depth log of the five rock type classes is derived for the wells CRC-2 and CRC-3 followed by their cross correlation to deduce the vertical and lateral continuity of rock types between the two wells.

The rock type classes within the two coastal to shallow-marine parasequences provide new insight into sub-seismic lithological heterogeneity and will support dynamic simulations accounting for sub-meter scale heterogeneity in multiphase flow and reactive transport simulations.

\section{Study Area Overview and Geological Setting}

\subsection{Study Area Overview}

The CO2CRC's Otway Research Facility site is located onshore of the Otway Basin. It is approximately $300 \mathrm{~km}$ southwest of Melbourne in Victoria, between the coastal towns of Port Campbell to the east, and Warrnambool to the west (Figure 1) [23]. The choice of the study area was determined by two factors. Firstly, the Paaratte Formation at the site contains abundant lithological 
heterogeneity [17-19] at sub-meter scale, and second, relevant field data on small scale lithological heterogeneity was made available through CO2CRC Limited.

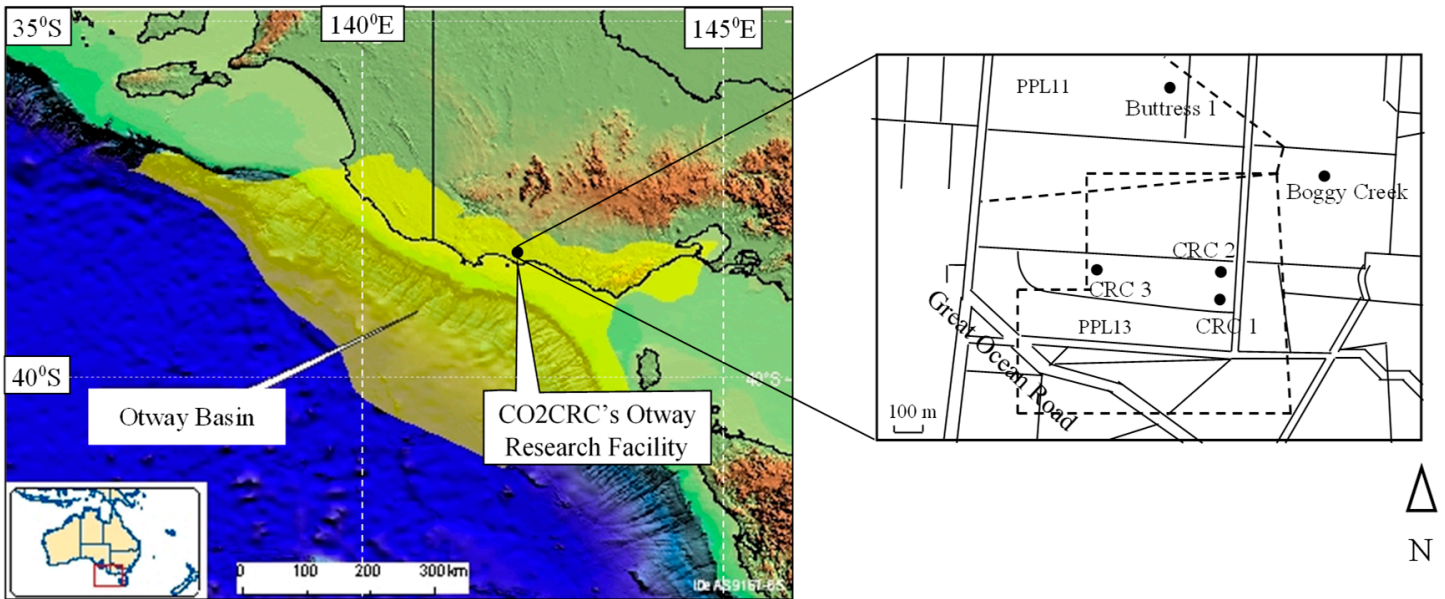

Figure 1. Location of the CO2CRC's Otway Research Facility, Otway Basin (modified after Geoscience Australia and $\mathrm{CO} 2 \mathrm{CRC}$ Limited).

While several wells exist at or nearby the CO2CRC's Otway Research Facility, the current study focuses on data from the wells CRC-2 (38 $\left.31^{\prime} 50.06^{\prime \prime} \mathrm{S}, 142^{\circ} 48^{\prime} 41.45^{\prime \prime} \mathrm{E}\right)$ and CRC-3 (38 $31^{\prime} 42.3^{\prime \prime} \mathrm{S}$, $142^{\circ} 48^{\prime} 17.8^{\prime \prime}$ E) $[19,24]$, because of the abundance and type of data available. The wireline and core data from both the wells have been characterized very well [19-22]. The two wells are located about 630 meters apart.

\subsection{Basin Location and Evolution}

The Otway Basin, which is a rift-to-passive margin basin that extends from the southeastern boundary of South Australia to the northwestern boundary of Tasmania [23,25]. The basin is about $500 \mathrm{~km}$ long. It covers a surface area of $150,000 \mathrm{~km}^{2}$ and is up to $8 \mathrm{~km}$ thick. The majority of the basin $\left(\sim 120,000 \mathrm{~km}^{2}\right)$ lies offshore up to $3000 \mathrm{~m}$ below sea surface [23,25-29].

An interplay of tectonic forces and sea level change shaped the present-day Otway Basin. The basin evolution began in Tithonian-Barremian stages with the first of the two rift events associated with the breakup of Australia and Antarctica [23,25,30-33]. The first rifting event led to thermal subsidence and regional sag during the Aptian to Albian stages [34], while the second rifting event was followed by passive margin subsidence [23,35].

The variation in tectonic forces over time led to a total of six major cycles of sea level change in the Otway Basin between Late Cretaceous and Quaternary. This resulted in the formation of five Groups in the Basin (oldest to youngest): Otway, Sherbrook, Wangerrip, Nirranda and Heytesbury [36]. The lowermost Otway Group precedes the first cycle of sea level change and the deposition was controlled by tectonic activity. The depositional environments of the Otway Group varied from volcaniclastic at the base to fluvial and shallow lacustrine at the top. The sediments deposited range from interbedded carbonaceous shale and basalts to interbedded volcaniclastic sandstone, mudstone and coal $[36,37]$. The effect of sea level change dominated the lithology with the commencement of the Sherbrook Group where the depositional environment varied from marginal marine within a low stand system tract at the base to upper deltaic plain environment within a high stand system tract at the top $[15,36,38]$. The sediments deposited include shale, black pyritic mudstone, siltstone, interbedded calcareous sandstone and coarse grained sandstone [36,39]. The Wangerrip Group consists of transgressive-regressive units [37] deposited under conditions varying from low energy marginal marine at the base to shallow-marine at the top. The sediments deposited include carbonaceous claystone, mudstone and sandstone [36,40-42]. The Nirranda Group developed in open marine 
conditions resulting in mixed carbonates and siliciclastic sedimentation [31,43], while the Heytesbury Group deposited during the sixth cycle of sea level change with a depositional environment varying from inner shelf at the base to mid-shelf at the top. The Heytesbury Group is composed of open marine carbonate sequences [36].

\subsection{The Paaratte Formation}

For the current study, the stratigraphic interval of interest at the CO2CRC's Otway Research Facility site lies between the depth of 1461-1565 m in the CRC-3 well and is a part of the Paaratte Formation belonging to the Sherbrook Group. The formation occurs between depths of $1120-1570 \mathrm{~m}$ with the depositional environment being lower delta plain belonging to a highstand system tract $[15,16]$. Lithologically, the Paaratte Formation is comprised of sandstone, siltstone and mudstone with carbonated intervals $[17,18,36]$.

Structurally, the Paaratte Formation is a low dipping faulted anticline with dips ranging between $2^{\circ}-5^{\circ}$ towards the north [16]. The formation comprises three member units, Unit A, Unit B and Unit C. Unit A (lowermost) comprises three fourth order parasequences with Parasequence- 1 at the bottom and Parasequence-3 at the top [22]. The current study focuses on Parasequence- 1 and -2 . Wireline data and core samples belonging to the two parasequences from wells CRC-2 and CRC-3 have been published previously [19-21] and the data interprested for sedimentary facies (Figure 2). The available wireline data used in the current study includes neutron porosity, apparent matrix density and gamma ray logs. The interpreted sedimentary facies have also been used, and comprise delta front, distal mouthbar, proximal mouthbar and distributary channel facies $[15,16,19]$. The delta front facies forms the bottommost facies in each of the two Parasequences and is overlain by distal mouthbar, proximal mouthbar and distributary channel facies.

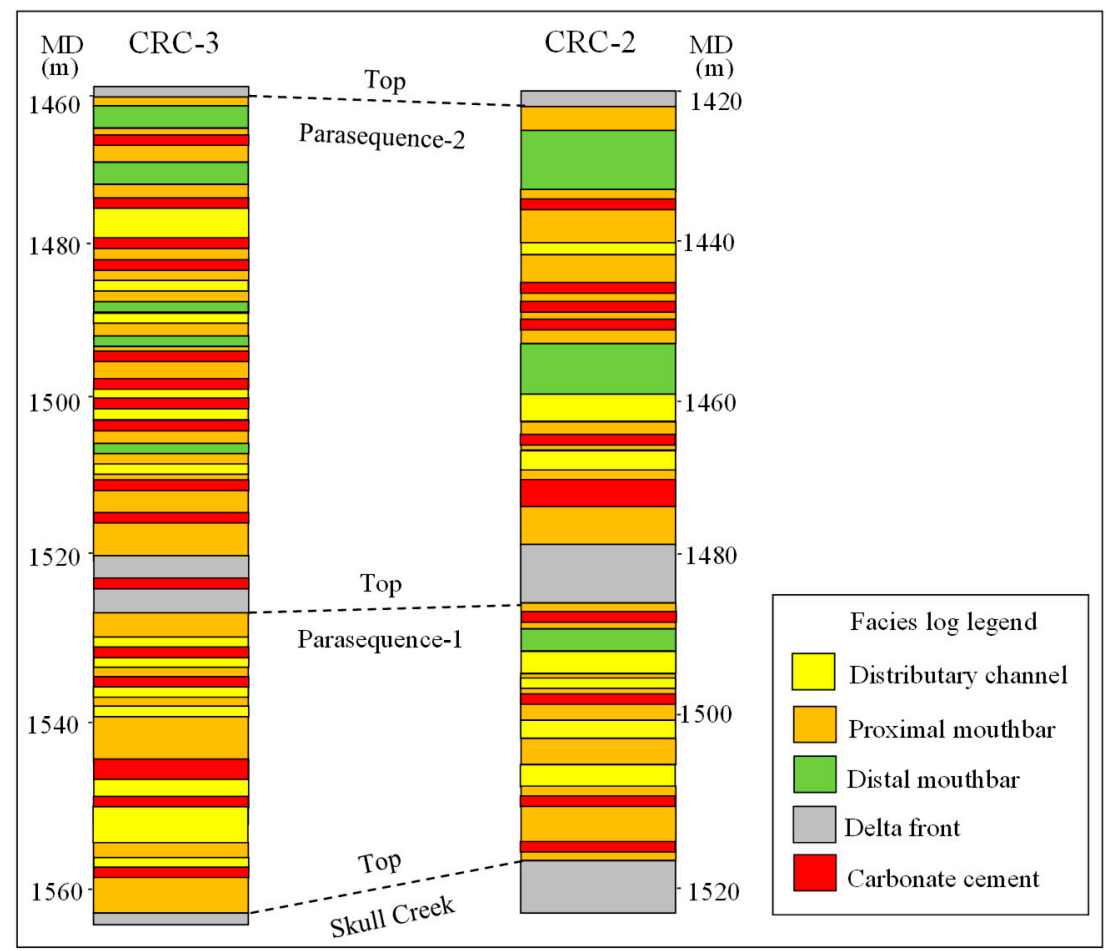

Figure 2. Representative facies logs against measured depth (MD) for wells CRC-3 and CRC-2. The four facies are: delta front, distal mouthbar, proximal mouthbar and distributary channel. The facies marked in red correspond to cemented zones [19,22,44].

The above-mentioned facies characterization and the previously published flow properties form the foundation of the work presented in this paper. 


\section{Methodology}

\subsection{Core Sampling and Analysis}

Cores of 100 meter length from the wells CRC-2 and CRC-3 were inspected visually and lithological variations described. Lithological heterogeneity was found to be abundant at sub-meter scales in the form of sedimentary structures. Broadly, three major types of sedimentary structures were identified: cross-bedding, planar bedding and massive bedding (Figure 3). The visual observation of grain sizes in the cores indicated the presence of three broad categories of lithological units: coarse grained, fine grained and cemented. Cross-bedding structures were characteristic of distributary channel facies and were dominated by coarse grained matrix and laminas of fine grained rock types. Core sections characterized by planar bedding were dominated by two different fine grained lithological units and were characteristic of the transition zone between the high energy facies such as distributary channel and proximal mouthbar and the low energy facies such as distal mouthbar and delta front. Massive bedding was typically tightly cemented and was characteristic of carbonate-cemented facies intervals. A visual grain size inspection was carried out in conjunction with the existing porosity and permeability data in order to select 30 representative samples for analysis such that they covered lithological units from all the observed grain sizes. The chosen core samples are described in Appendix A.

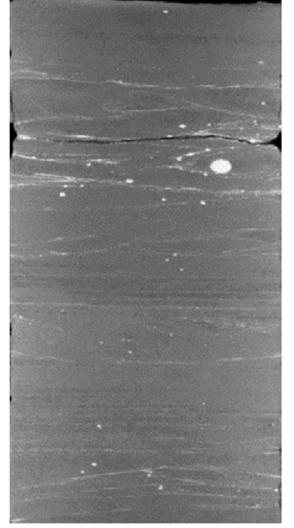

(a)

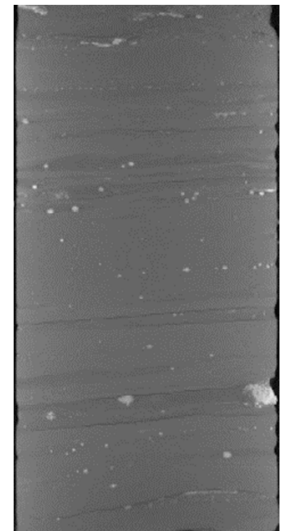

(b)

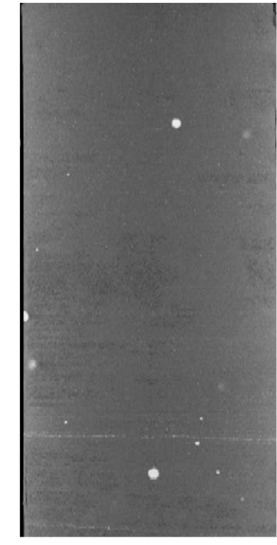

(c)

Figure 3. X-ray images showing the major sedimentary structures observed in the cores between 1535 and 1538 m from CRC-3 well at the CO2CRC's Otway Research Facility [45]. (a) Cross-bedding; (b) Planar bedding; (c) Massive bedding. Thin laminae of fine grained rock type (light gray) can be identified between more coarse grained rock type (dark gray) in cross beddings (a). The planar bedding (b) consists of a bimodal distribution of finer grain sizes (dark and light gray). The massive bedding (c) is tightly cemented and structureless. Each image measures $25 \mathrm{~cm}$ (vertical) and $10 \mathrm{~cm}$ (horizontal).

\subsubsection{Porosity, Permeability and Capillary Entry Pressure Analysis}

Porosity and permeability data used in this study were published elsewhere $[19,22]$ and were analyzed here in terms of their abundances in different facies. Frequency plots were constructed for the two properties for each of the four facies where number of data values were 30, 105, 9 and 30 for distributary channel, proximal mouthbar, distal mouthbar and delta front facies, respectively, from the entire Paaratte Formation. Out of these, 82 data values belong to the two parasequences of interest (Appendix B, Table A3). The frequency plots provide insights into the distribution of porosity and permeability within each depositional facies which in turn, is genetically related to changes in energy in varying depositional environments and potential diagenetic cementation. Published MICP data has been used to derive the equivalent height of a $\mathrm{CO}_{2}$ column that the given sample can hold before $\mathrm{CO}_{2}$ 
enters the sample $[20,21]$. Under this condition, the capillary entry pressure $\left(P_{e}\right)$ becomes equal to the buoyancy pressure $\left(P_{b u}\right)$, which can be expressed in terms of $\mathrm{CO}_{2}$ column height (Equation (1)) [46].

$$
P_{e}=P_{b u}=0.433 \Delta \rho h_{F W L}
$$

where $\Delta \rho$ is the density difference between brine and supercritical $\mathrm{CO}_{2}, h_{F W L}$ is the height of $\mathrm{CO}_{2}$ above free water level (FWL) and 0.433 is the pressure gradient in psi/ft.

The sample specific values of entry pressures have been used to determine the broad range of entry pressures for each rock type class.

\subsubsection{Quantitative Mineral Composition Analysis}

Quantitative Evaluation of Minerals by Scanning Electron Microscopy is referred to as QEMSCAN and is an automated technique that combines SEM and energy dispersive X-ray spectroscopy analysis and produces a high resolution 2D mineral map of a polished rock surface. The technique is used to quantify the mineral composition in terms of the area occupied by the minerals $[47,48]$. The results from QEMSCAN analysis are used to distinguish rock type classes based on their mineral content. The analysis was done on a sample area of $1 \mathrm{~cm}^{2}$ where each pixel on the mineral map corresponds to a length of $5.93 \mu \mathrm{m}$.

The QEMSCAN analysis was done on 30 thin sections prepared on samples from the CRC-3 core (Section 3.1, Appendix A). The proportion of major minerals in the four facies is evaluated using the QEMSCAN results corresponding to samples from each facies. As the samples are chosen from all four facies, it is possible to obtain an average value of the volume fraction of different minerals for each facies along with an estimate of their respective deviations.

\subsubsection{Mineral Specific and Total Grain Size Analysis}

The 2D mineral maps derived by QEMSCAN were further used to determine the spectrum of equivalent grain diameter for each mineral. The grain size analysis was conducted using the Avizo software package (Thermo Scientific $\left.{ }^{\mathrm{TM}}\right)$. Backscattered electron images and QEMSCAN mineral maps were imported into Avizo with a resolution of 6 micrometers and converted to their RGB components to help distinguish segmented mineral phases. Specific values of RGB were then used to separately segment the area occupied. A threshold of $0.1 \%$ was applied as the minimum segmented area of each mineral. The Separate Objects algorithm in Avizo was used to create artificial grain boundaries for separating the grains which were too close. The artificial grain boundaries were validated using the backscattered electron image. The grain boundaries were manually adjusted where a mismatch was observed from the backscattered electron image. The number of pixels segmented to each mineral were used to calculate their respective area fractions using the Volume Fraction algorithm in Avizo. The size of separated grains was determined using the Label Analysis algorithm in Avizo and the EqDiameter $(E q D)$ measure, which determines the equivalent circular diameter of a grain based on the segmented area $(S A)$ it occupies (Equation (2)).

$$
E q D=\sqrt{\frac{4 X S A}{\pi}}
$$

Mineral specific grain size distributions were produced for each sample by binning the area fraction occupied by mineral grains within specific limits of $E q D$ (Equation (2)). The modal grain sizes for different samples are then used to determine facies specific grain size distribution.

\subsubsection{Hyperspectral Core Logging}

Hyperspectral core logging is a method used to derive a continuous log of semi-quantitative mineral composition in cores. The system used here is referred to as Hylogger ${ }^{\mathrm{TM}}$. It is a non-invasive, non-destructive method and measures the reflectances in the Visible-Near InfraRed (VNIR), Short-Wave 
InfraRed (SWIR), and Thermal InfraRed (TIR) wavelengths [47,49]. The reflectances are then analyzed in The Spectral Geologist ${ }^{\mathrm{TM}}$ (TSG) which is a software platform for interpreting the mineral reflectance [50]. It is based on the optimization of fitting individual mineral spectra to a measured spectra from a rock sample. Consequently, it is possible to estimate the most dominant minerals at $\mathrm{cm}$ scale resolution. These algorithms are built on a library of approximately 500 end member reflectance spectra for commonly occurring minerals [47].

Previous validation work of TIR data suggests a successful correlation with other sample analysis methods like X-ray diffraction (XRD), X-ray fluorescence (XRF) and microprobe data [51,52]. The main limitation of hyperspectral logging data is that it only provides counts for the identified minerals and that the technique does not pick up minerals occurring in trace amounts [47].

Hyperspectral core logging was performed on the 104-meter section of the core from the CRC-3 well covering Parasequence- 1 and -2 and TIR data were used for further analysis. The hyperspectral logging resulted in depth continuous measurement of mineral counts at a resolution of $4 \mathrm{~cm}$. The data has then been binned into depth intervals of $20 \mathrm{~cm}$, thus averaging five mineral count values in this interval. The counts are converted into mineral proportions, which were then grouped into three end member mineral classes characteristic of siliciclastic reservoirs [52]. The mineral classes are: framework minerals (quartz and feldspar), clay minerals (mica, kaolinite, smectite, chlorite) and carbonate minerals (calcite and dolomite). The minerals detected in trace amounts have not been assigned to any end member mineral class. These mineral proportions were accounted for when the rock type classification was developed.

\subsection{Wireline Logging and Data Analysis}

\subsubsection{Available Wireline Log Data Analysis}

Neutron porosity, apparent matrix density and gamma ray wireline logs from CRC-2 and CRC-3 [22] were used in this study. The wireline logs express porosity, density and clay abundance and have been used to derive rock type classes at $10 \mathrm{~cm}$ resolution (Section 3.2.2). Additionally, this study makes use of the Elemental Capture Spectroscopy (ECS) log for CRC-3 [44]. The ECS is a technique developed by Schlumberger which provides relative abundance of common elements such as silicon, iron, calcium, titanium, sulfur and gadolinium based on the principles of pulsed neutron spectroscopy [53]. The data from the ECS log is used to further cross validate mineral abundance derived from other methods presented in this study.

\subsubsection{Deriving Lithotype Logs}

Three wireline log data sets (apparent matrix density, neutron porosity and gamma ray) were combined to derive lithotype logs using the Kimeleon software [54,55].

Kimeleon improves on the differentiation and identification of lithologies by integrating more than one log; thus avoiding a bias caused by fluid volume that is associated with single porosity readings. Relative dispositions of the three input logs are reliably indicative of the mineralogy and by extension of the rock type, which is reflected in the color gradient pictured by lithotype log [55].

The apparent matrix density log is implemented as the red channel, neutron porosity log is implemented as the green channel and gamma ray log is implemented as the blue channel. The three logs are then combined to produce a composite representative color known as the colourlith. The combination of magnitudes from of apparent matrix density, neutron porosity and gamma ray from wireline data for each depth is unique. The information of individual log curves is transferred and preserved in the colourlith where variation in hue reflects the magnitude of the combined logs.

The lithotype analysis was undertaken for Parasequences- 1 and -2 between the depths of 1461 and $1565 \mathrm{~m}$ in CRC-3 and between 1422 and $1518 \mathrm{~m}$ in CRC-2. Wireline log LAS files were corrected for variations in distances between individual measurements and for duplicate measurements before importing them into Kimeleon. The three false color representations were combined in an in-built 
model within Kimeleon known as the Rhomaa-NPHI model. The model estimates absolute density by combining apparent density and neutron porosity and integrates this information with gamma ray values to result in the colourlith log. The advantage of using the Rhomaa-NPHI model is that it is known to perform well in discriminating between shale, carbonate-rich rock (dolomite and limestone) and sandstones [55]. Kimeleon allows limit manipulation for each of the properties, which can enhance or diminish the detail as more extreme magnitudes are being included or excluded. This is reflected in the recognition of more subtle differences between rock properties and thus increased or decreased color variety. Some limit adjustments were required to enhance the difference between siltstone and mudstone and thus the color coding is different from Kimeleon's default.

To confirm the results, the colourlith log derived for CRC-3 was compared to the mineral composition derived by ECS. Even though these outputs are not strictly independent as they are both based on the same dataset, the colourlith and the ECS logs are based on different techniques.

The colourlith log was analyzed for the differences in hues which are then interpreted as specific rock types. CRC-3 served as the primary rock record as it provided the most abundant data (hyperspectral core log, wireline log, sample analysis). Hence, based on the similarity in the colourlith logs of the two wells, the CRC-2 colourlith is assigned rock types equivalent to those in CRC-3. The vertical resolution of the rock record is $10 \mathrm{~cm}$ due to the in-built limitations of Kimeleon. The output results in the vertical extent of each rock type class in the two wells in the form of rock type logs. The patterns in the two rock type logs were then used to deduce the lateral extent of rock types between the wells.

\section{Results}

\subsection{Sample Analysis Results}

\subsubsection{Porosity, Permeability and Entry Pressure Analysis}

The frequency distribution plots (Figure 4) show a bimodal distribution of porosity and permeability for distal mouthbar and delta front facies and a normal distribution for the distributary channel facies. A minor bimodal distribution is found for the proximal mouthbar facies. The highest porosity and permeability values are observed for distributary channel while the lowest values are observed for delta front facies. Two classes of dominant porosity and permeability can be defined corresponding to the bimodal distribution: a first class with porosity greater than 0.25 and permeability greater than $100 \mathrm{mD}$ and a second class with porosity and permeability smaller than these values.

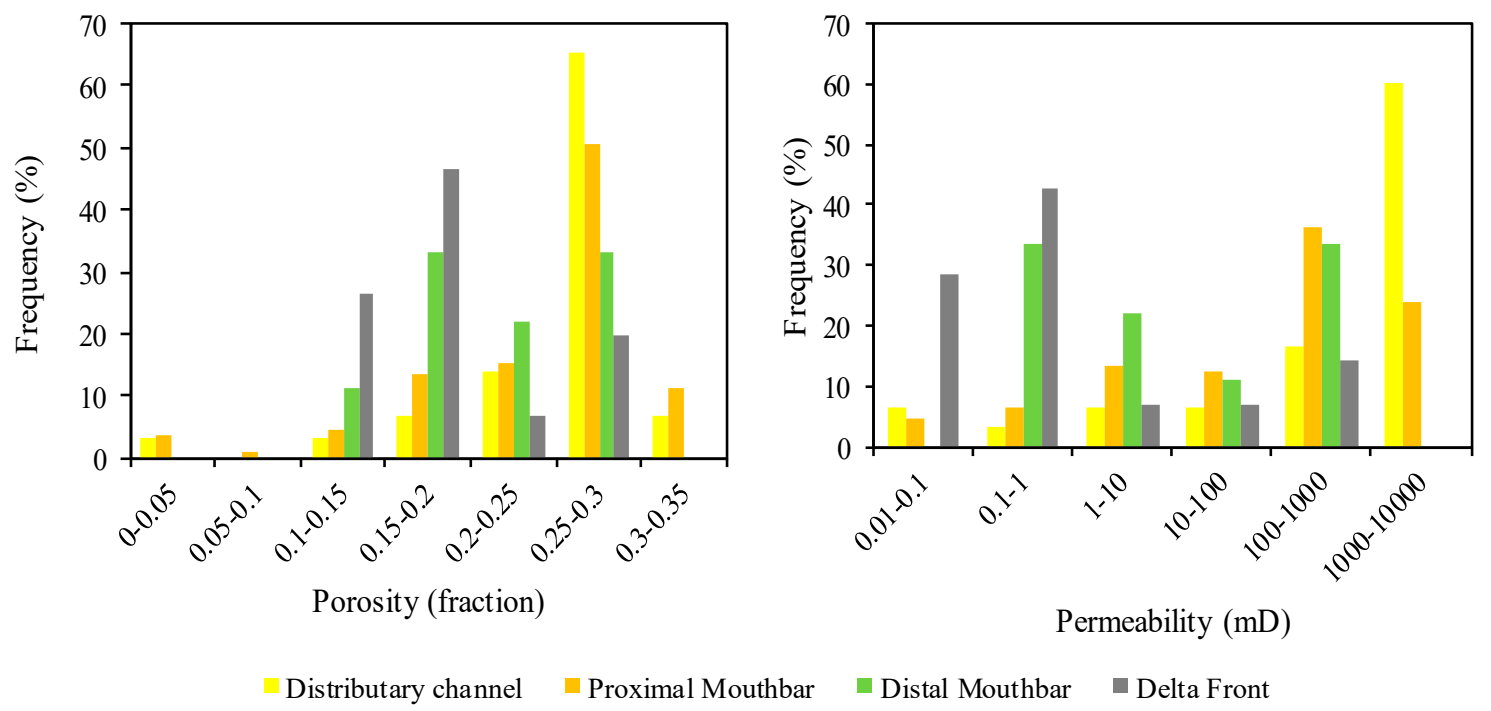

Figure 4. Frequency distribution of porosity and permeability values measured for discrete core samples from wells CRC-2 and CRC-3 for each facies. 
The previously reported equivalent $\mathrm{CO}_{2}$ column height data from CRC-2 for samples belonging to the depths $1434.70 \mathrm{~m}, 1435.31 \mathrm{~m}, 1439.72 \mathrm{~m}, 1440.21 \mathrm{~m}, 1448.58 \mathrm{~m}, 1485.39 \mathrm{~m}, 1491.43 \mathrm{~m}, 1504.45 \mathrm{~m}$, $1507.65 \mathrm{~m}$ and $1509.88 \mathrm{~m}[20,21]$ is used to calculate capillary entry pressures for the respective samples (Equation (1)). The calculated entry pressure varied between $300 \mathrm{~Pa}$ and 160,000 $\mathrm{Pa}$ (Table 1) and is expected to represent the entry pressure for the range of rock types. A conversion factor of 6894.76 was used convert the units from psi to Pa.

Table 1. Capillary entry pressures $\left(\mathrm{P}_{\mathrm{e}}\right)$ calculated from given $\mathrm{CO}_{2}$ column height above the free water level $\left(\mathrm{h}_{\mathrm{FWL}}\right)$ for discrete samples.

\begin{tabular}{ccccccccccc}
\hline Depth $(\mathbf{m})$ & 1434.7 & 1435.3 & 1439.7 & 1440.2 & 1448.6 & 1485.4 & 1491.4 & 1504.5 & 1507.7 & 1509.9 \\
\hline $\mathbf{h}_{\mathbf{F W L}} \mathbf{( m )}$ & 40.21 & 5.18 & 2.77 & 42.12 & 45.31 & 5.21 & 9.15 & 0.21 & 0.18 & 0.27 \\
$\mathbf{P}_{\mathbf{e}} \mathbf{( k P a )}$ & 142.3 & 18.5 & 9.7 & 149.8 & 160.1 & 18.5 & 32.1 & 0.7 & 0.6 & 0.9 \\
\hline
\end{tabular}

\subsubsection{Quantitative Mineral and Mineral Specific Grain Size Analysis}

Results obtained from the QEMSCAN analysis include identification of mineral phases making up the respective samples, the areal proportion each mineral occupies on the polished 2D thin section surface and the mineral map of the polished surface. Figure 5 shows mineral maps and major mineral phases for the representative samples from distributary channel (sample \#93), proximal mouthbar (sample \#91) and distal mouthbar (sample \#81) facies. The mineral maps provide visual mineralogical and textural information. Clay content increases from sample \#93 to Sample \#81 while the grain sizes decrease in the same order. The black area on the mineral maps represents porosity.

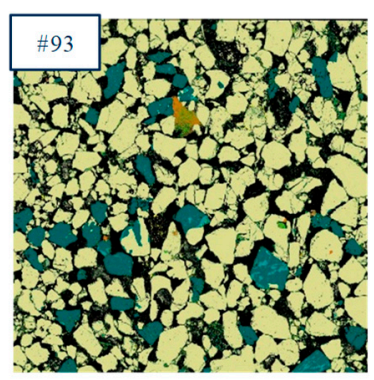

(a)

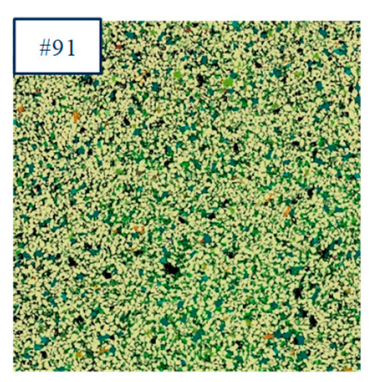

(b)

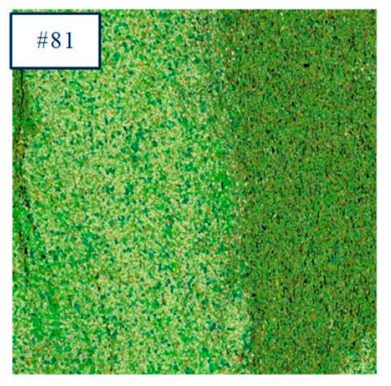

(c)

Figure 5. Results from QEMSCAN analysis for samples: (a) \#93 (distributary channel); (b) \#91 (proximal mouthbar); (c) \#81 (distal mouthbar).

The minerals detected include framework minerals such as quartz, alkali feldspar and plagioclase; clay minerals such as chlorite, illite, kaolinite, muscovite, pyrophyllite, palygorskite and smectite; and carbonate minerals such as calcite, ankerite, dolomite, siderite and magnesite along with trace minerals such as rutile, pyrite, ilmenite and zircon. Figure 6 shows the proportion of major minerals in each facies. The QEMSCAN results for samples chosen from distributary channel and proximal mouthbar facies are dominated by framework minerals like quartz and feldspar while the samples chosen from distal mouthbar and delta front facies show a higher proportion of clay minerals like kaolinite, illite, chlorite and smectite. The proportion of quartz ranges between $60-90 \%$ in distributary channel samples and decreases to $30-70 \%$ in distal mouthbar and delta front samples. The proportion of clay minerals such as chlorite, illite, smectite and kaolinite is higher in distal mouthbar and delta front facies where it varies between $10-20 \%$ as compared to distributary channel and proximal mouthbar facies where their maximum amount is less than $10 \%$. From the results, the bulk clay mineral proportion for distributary channel and proximal mouthbar varies between $\sim 10 \%$ to $~ 30 \%$ and for distal mouthbar and delta front varies between $25 \%-60 \%$. A detailed description of the mineral maps of all the 30 samples along with quantitative mineralogy is given in Appendix C. 


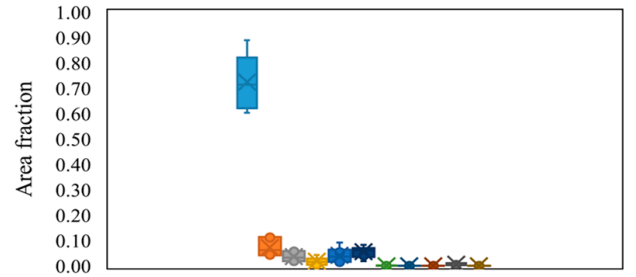

(a)

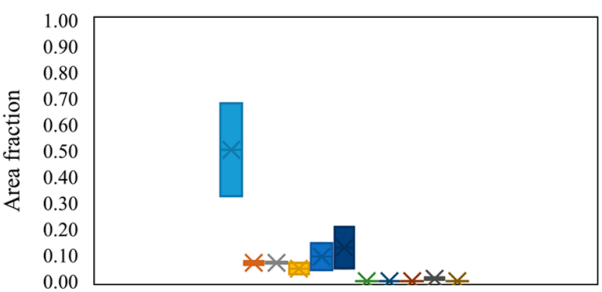

(c)

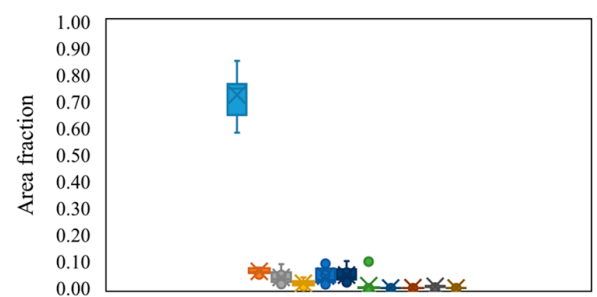

(b)

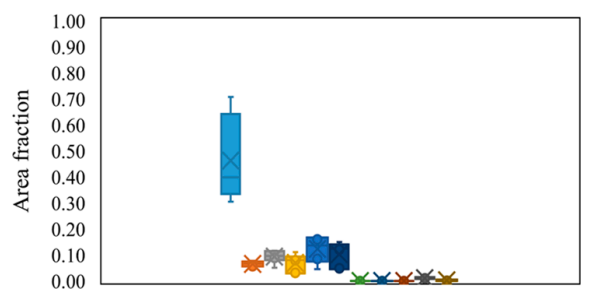

(d)

Figure 6. Proportion of major minerals in: (a) Distributary channel; (b) Proximal mouthbar; (c) Distal mouthbar; (d) Delta front. Box-and-whisker plots show mean (cross within the box), median (bar within the box), 25th and 75th quartile (lower and upper boundary of the box) and lower and upper limit of the data range (ends of the whisker).

The equivalent grain diameter of minerals varies between $0.01 \mathrm{~mm}$ to $\sim 0.6 \mathrm{~mm}$. Figure 7 shows the modal grain size distribution characteristic of each facies. The modal grain size is as high as $0.6 \mathrm{~mm}$ for distributary channel facies. The modal grain size decreases subsequently in proximal mouthbar, distal mouthbar and delta front facies. The latter two facies are characterized by modal grain size smaller than $0.1 \mathrm{~mm}$. The data was further used to plot area fraction covered against equivalent grain diameter for each mineral. The results for all the samples are presented in Appendix D.

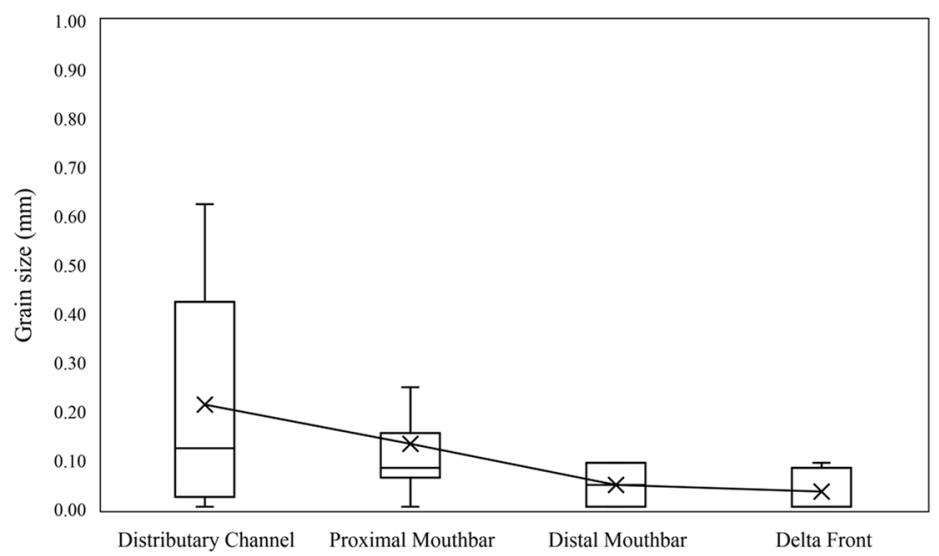

Figure 7. Modal grain size distribution characteristic of the four facies. Box-and-whisker plot shows mean (cross within the box), median (bar within the box), 25th and 75th quartile (lower and upper boundary of the box) and lower and upper limit of the data range (ends of the whisker).

\subsection{Hyperspectral Reflectance Analysis}

Figure 8a shows the results obtained from the hyperspectral (TIR) core analysis for CRC-3. The minerals detected include framework minerals like quartz and alkali feldspar; clay minerals such as mica, kaolinite, smectite and chlorite; and carbonate minerals such as dolomite and calcite along with some minerals present in trace amounts like illite, siderite, magnesite, ankerite, rutile and ilmenite. Quartz is the most dominant mineral detected in the core. Among the clay minerals, kaolinite and smectite are the most dominant. Their proportion varies through depth. Six different 
carbonate-cemented layers have been observed between the depths of 1480 and $1482 \mathrm{~m}(\mathrm{Cb}-1), 1508 \mathrm{~m}$ (Cb-2), 1514 and $1515 \mathrm{~m}$ (Cb-3), 1532 and $1533 \mathrm{~m}$ (Cb-4), 1547 and $1549 \mathrm{~m}(\mathrm{Cb}-5)$ and 1556 and $1558 \mathrm{~m}$ (Cb-6). Clay minerals are dominant between depths of 1461 and $1475 \mathrm{~m} \mathrm{(Cl-1)}$ and between 1520 and 1530 meters (Cl-2), while framework minerals dominate between depths of 1475 and $1480 \mathrm{~m}$ (F-1). Intercalations of clay minerals with the framework minerals occur between the depths 1483 and $1507 \mathrm{~m}$ (I-1), 1535 and $1545 \mathrm{~m}$ (I-2) and between 1548 and $1557 \mathrm{~m}$ (I-3). These intercalated zones depict the depths of intraformational baffles.

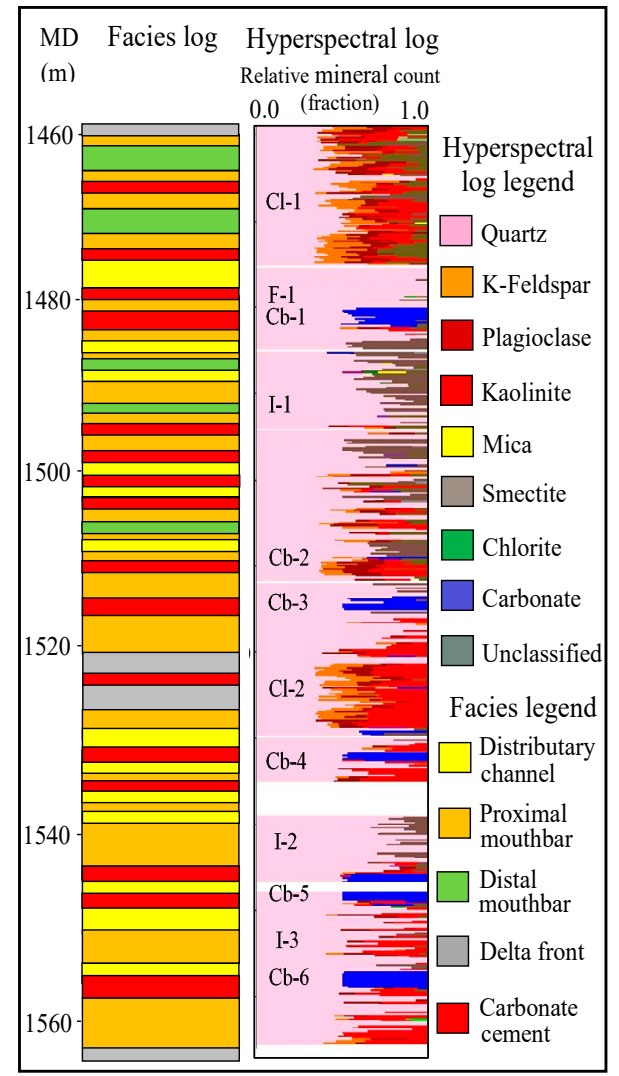

(a)

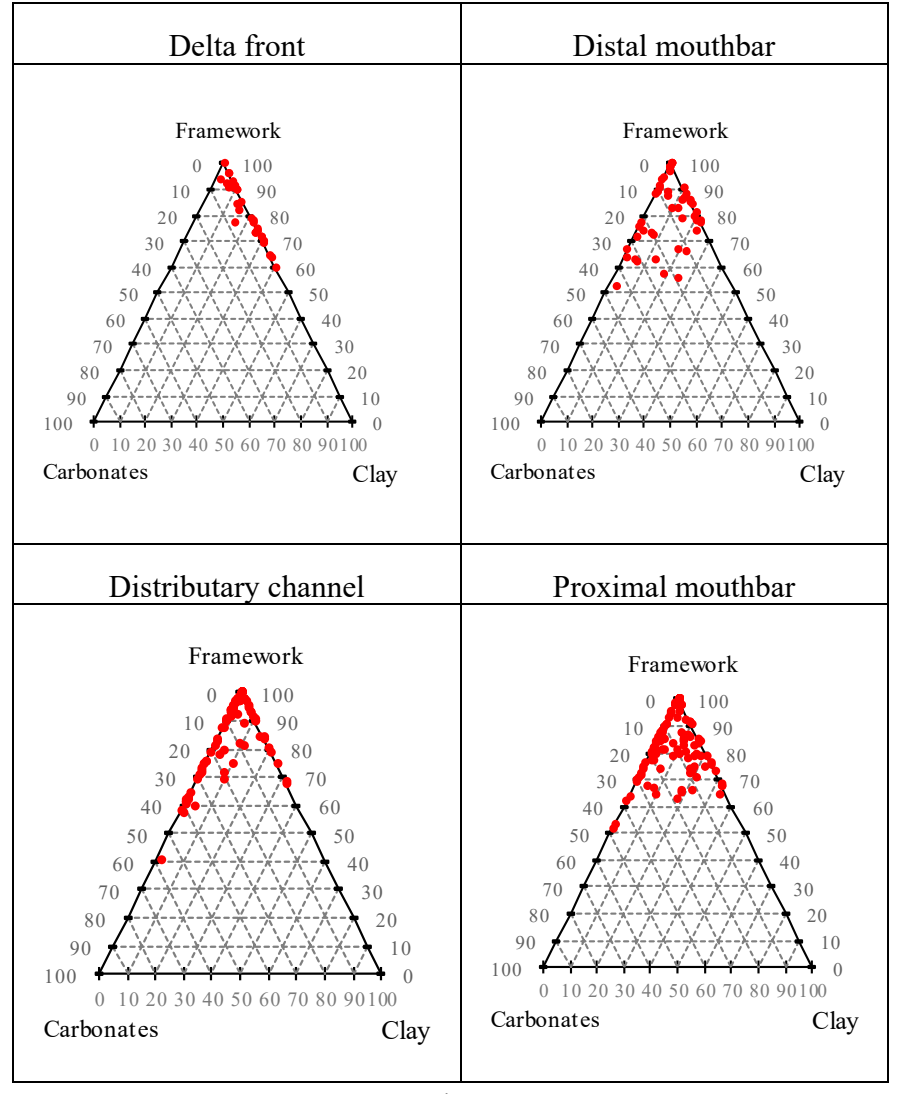

(b)

Figure 8. (a) Relative mineral count log as obtained by hyperspectral logging compared with the facies $\log$ for the CRC-3 core. The hyperspectral log shows various layers rich in framework (F), clay $(\mathrm{Cl})$ and carbonate $(\mathrm{Cb})$ minerals. The layers rich in clay intercalated within the framework minerals (I) are also shown; (b) Ternary plots showing the relative abundance of the three end member mineral classes in each of the four facies.

Figure $8 \mathrm{~b}$ shows the proportion of the three end member mineral classes for each of the four facies as obtained from normalizing the respective contents of the major minerals. The proportion of the clay minerals is less than $30 \%$ in distributary channel while it is as high as $40 \%$ in delta front deposits. The proximal and distal mouthbars have intermediate clay content. The proportion of carbonates is less than $10 \%$ in delta front but reaches up to $60 \%$ in distributary channel sediments.

\subsection{Colourlith and ECS Logs and Their Correlation}

Colourlith logs are compared with the ECS log [24] (Figures 9 and 10) showing that high proportions of quartz and feldspar correspond with red hue, while sequences with higher clay content agree with a blue hue. The presence of carbonates closely corresponds with a green hue. The three major shades also indicate the presence of three broad rock types. Furthermore, the red hue transitions into purple and greenish blue shades before merging with the blue hue, which is representative of clay 
rich intervals. This indicates the presence of two additional rock types between the framework and clay rich end members.

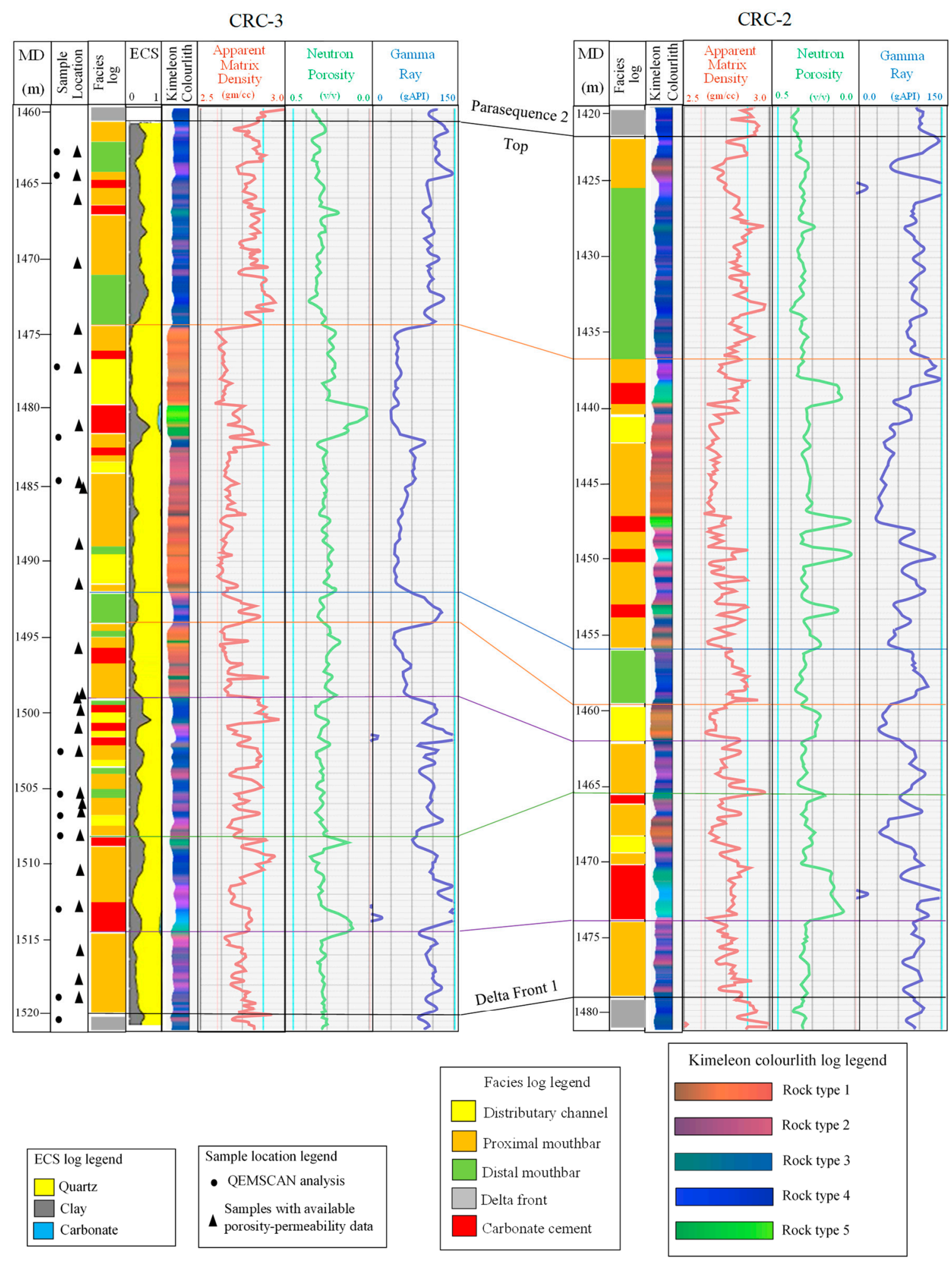

Figure 9. Colourlith logs for Parasequence-2 of well CRC-2 and CRC-3. The ECS log [24] is matched against the colourlith log and the hues in the two wells are cross correlated. 


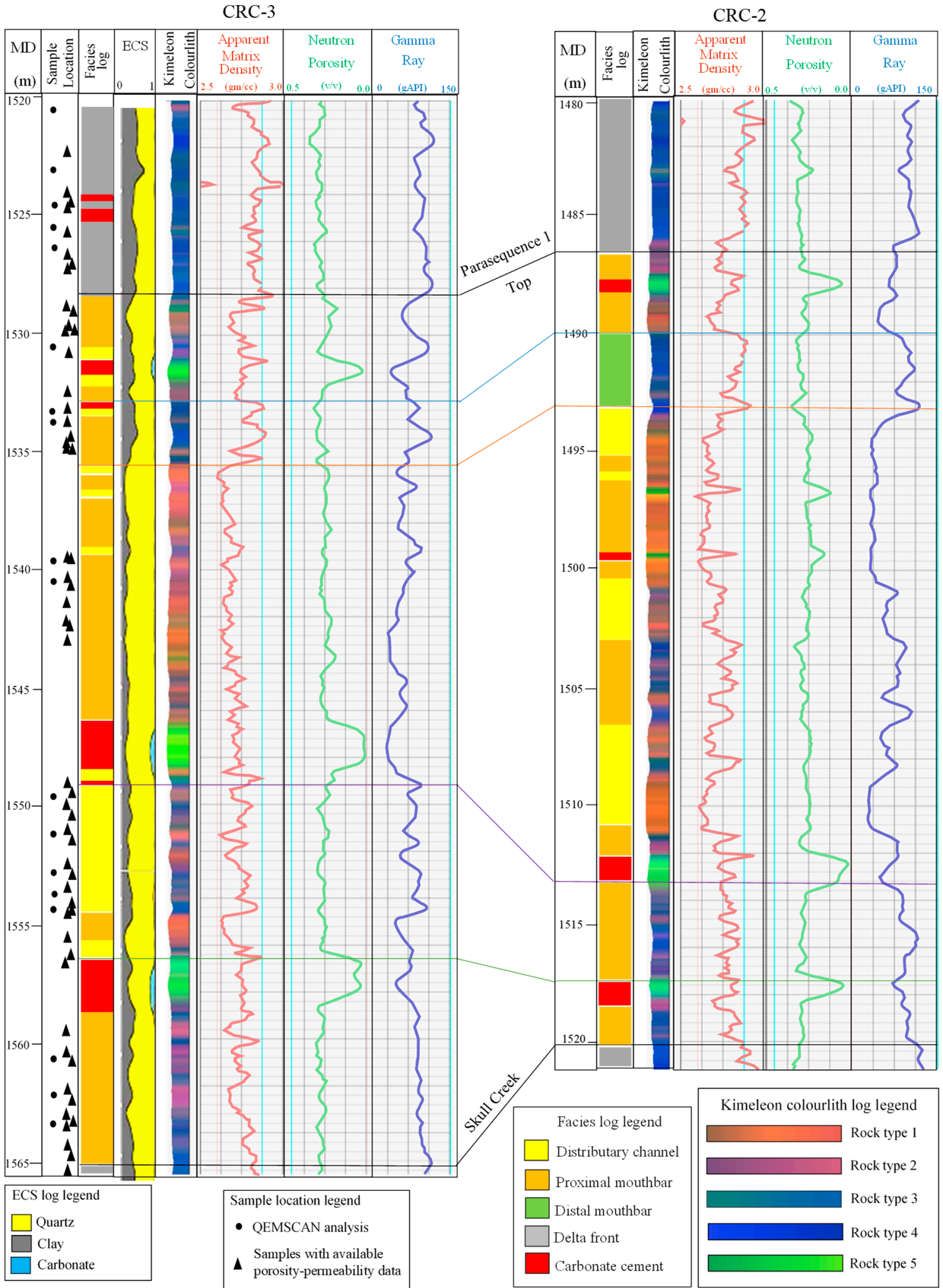

Figure 10. Colourlith logs for Parasequence- 1 of wells CRC-2 and CRC-3. The ECS log [24] is matched against the colourlith log and the hues in the two wells are cross correlated.

Hence, the analysis of colourlith logs leads to five rock type classes observed in the two parasequences: rock type 1 (red), rock type 2 (purple), rock type 3 (greenish blue), rock type 4 (blue) and rock type 5 (green). 
Parasequence-2 (Figure 9) in CRC-3 ranges between 1461.6 and $1525 \mathrm{~m}$ depth. Overall, there are three distinctive sections, two clay dominated sections at the top and the bottom with a sand dominated section in the middle. The top clay section starts at $1461.6 \mathrm{~m}$ but extends to the overlying delta front facies and terminates at $1474.6 \mathrm{~m}$. There are occasional interbedded sands and thin carbonated layers. The sand dominated section between 1474.6 and $1499.2 \mathrm{~m}$ is interrupted twice by clays at 1482 and $1492.4 \mathrm{~m}$, which are 0.4 and $1.8 \mathrm{~m}$ thick respectively. Parasequence- 2 in CRC-2 ranges from 1420 to $1486 \mathrm{~m}$ depth. It starts with a $15 \mathrm{~m}$ thick clay dominated layer with occasional sand extending to the overlying delta front facies. A $2 \mathrm{~m}$ thick carbonate-rich layer is identified at $1438 \mathrm{~m}$. A $15 \mathrm{~m}$ thick sand bed ranges between 1440 and $1455 \mathrm{~m}$ depth. Towards the bottom of the interval, the lithology is clay dominated with minor intervals of sand. Additional carbonate-rich layers are identified at $1447 \mathrm{~m}, 1454 \mathrm{~m}, 1465 \mathrm{~m}$ and $1472 \mathrm{~m}$. Parasequence-2 terminates at the base of delta front facies, which is clay dominated.

Parasequence-1 (Figure 10) in CRC-3 ranges between 1525 and $1565.2 \mathrm{~m}$ depth. The changes between lithologies are progressive. The profile starts at the top with a clay dominated sequence $(1525-1535.4 \mathrm{~m})$ that overlies a delta front facies with numerous sand interbeds; two carbonate layers occur at 1528.8 and $1531.6 \mathrm{~m}$. The interbedded sand layer transitions into mudstone with depth, which transitions towards the base into the underlying Skull Creek Formation. Two carbonate-rich layers have been identified at 1546.4 and $1556.4 \mathrm{~m}$, which are 2.8 and $2 \mathrm{~m}$ thick respectively. Parasequence- 1 in CRC-2 ranges from 1486 to $1518 \mathrm{~m}$ depth. It starts with a clay layer and transitions into a $2.7 \mathrm{~m}$ thick layer of sand. The remaining part of Parasequence- 1 consists of interbedded clay and sand layers. Similar to CRC-3, the abundance of clay increases with depth and into the Skull Creek. There are two carbonate-rich layers at 1512 and 1517.3 , which are 1.4 and $0.8 \mathrm{~m}$ thick respectively.

The sequence of rock types reflected in the two colourlith logs is similar for both parasequences and is traceable between the wells. As the distance between the well is only $630 \mathrm{~m}$, the similarity in the rock type pattern is reasonable and lends confidence in the cross-well correlation of mud rich facies such as delta front and distal mouthbar (Figures 9 and 10). The rock types constituting sand rich facies such as distributary channel cannot be confidently correlated as channels are known to be discontinuous between the two wells [22].

\section{Discussion}

\subsection{Rock Types and Properties}

Hyperspectral core logging, the combined wireline logs and discrete sample analysis show that there is significant lithological heterogeneity within Parasequence- 1 and Parasequence- 2 of the Paaratte Formation at the CO2CRC's Otway Research Facility. The porosity and permeability analysis shows a bimodal distribution within the distal mouthbar and the delta front facies (Figure 4), which suggests that the depositional environment was characterized by phases of low and high energy. The bimodal distribution of porosity and permeability for distributary channel and proximal mouthbar are skewed towards higher porosity and permeability values indicating their primary deposition under higher energy conditions where medium to coarse sand is deposited. Grain size analysis confirms a coarse grained quartz and feldspar rich lithology with a modal grain size of $0.21 \mathrm{~mm}$ and $0.13 \mathrm{~mm}$ for distributary channel and proximal mouthbar, respectively (Figures 5-7). The larger grain size for the samples belonging to distributary channel facies is expected as proximal mouthbars are located further downstream of the distributary channel facies and consequently experiences lower depositional energy conditions. Low porosity and permeability is more common in distal mouthbar and delta front facies (Figure 4) indicating sediment deposition under lower energy conditions. Clay size particles are expected to be dominant under such low energy conditions. This is confirmed by grain size analysis as the samples belonging to distal mouthbar and delta front facies show a higher proportion of clay minerals with modal grain size less than $0.05 \mathrm{~mm}$ (Figures 5-7). The clay content increases while grain size decreases from distributary channel to proximal mouthbar and further to distal mouthbar and 
delta front facies. It is clear that the variations in physical properties and the mineral composition result from changes in the energy of the depositional environment.

The porosity and permeability results are coupled with the results from grain size analysis, semi-quantitative and quantitative mineral compositions to define rock type classes.

The bimodal distribution of porosity and permeability (Figure 4) suggests to subdivide the entire porosity spectrum into two categories or rock type classes: a. rocks with a porosity and permeability greater than 0.25 and $100 \mathrm{mD}$, respectively, and b. rocks with a porosity and permeability values less than 0.25 and $100 \mathrm{mD}$, respectively. However, the range in permeability for the two rock types is large and would lead to a large uncertainty in flow simulations. We have therefore further classified the data. The former class is subdivided into two subcategories: a. with permeability values less than $10 \mathrm{mD}$, and $\mathrm{b}$. with permeability values between $10-100 \mathrm{mD}$. Similarly, the latter permeability class is subdivided into two subcategories: a. with permeability values between $100-1000 \mathrm{mD}$, and $\mathrm{b}$. with permeability values greater than $1000 \mathrm{mD}$.

Rock types were further constrained in terms of their mineral composition using the semi-quantitative and quantitative mineral analysis. The results from hyperspectral analysis were used to characterize the rock types in terms of bulk carbonate content as the Hylogger output helps in the identifies carbonate-cemented zones (Figure 8). A threshold of $5 \%$ carbonate mineral fraction was chosen as a distinguishing criteria between the carbonate and non-carbonate samples for the purpose of rock type characterization. This criteria is later confirmed by the results obtained from QEMSCAN analysis.

The combined criteria of porosity and permeability and the semi-quantitative mineral composition as described above was applied to the five preliminary rock type classes from the colourlith analysis. The resultant rock type classes and their respective properties are described as: coarse sandstone (porosity $>0.25$; permeability $>1000 \mathrm{mD}$; carbonate mineral proportion $<5 \%$ ), fine sandstone (porosity $>0.25$; permeability between $100-1000 \mathrm{mD}$; carbonate mineral proportion $<5 \%$ ), siltstone (porosity < 0.25; permeability between $10-100 \mathrm{mD}$; carbonate mineral proportion $<5 \%$ ), mudstone (porosity $<0.25$; permeability $<10 \mathrm{mD}$; carbonate mineral proportion $<5 \%$ ), carbonate-cemented sandstone (porosity $<0.25$; permeability $<1000 \mathrm{mD}$; carbonate mineral proportion $>5 \%$ ). 80 out of the total 82 samples fall into one of the five categories (Table A3, Appendix B). The remaining 2 data points remain unclassified.

The five preliminary rock type classes are further constrained in terms of bulk clay content based on QEMSCAN results. Quantitative mineralogy data from the 30 samples (Appendix C) was first assigned to one of the five 5 preliminary rock type classes based on the knowledge of available porosity and permeability data (Table A2, Appendix B). Hence, 5 samples fell under rock type 1, 13 under rock type 2, 4 under rock type 3, 7 under rock type 4 and 1 under rock type 5 (Table A2, Appendix B). The mean proportion of each mineral was calculated based on the QEMSCAN analysis for each rock type class along with their standard deviations (Table 2).

As can be seen from Table 2, the standard deviations of different mineral fractions for each rock type class are typically small. The mineral composition data from QEMSCAN analysis is added to rock type classes in terms of the range of bulk clay mineral content obtained for all samples belonging to each rock type class. Clay mineral content for coarse sandstone rock type class varies between $5-20 \%$; for fine sandstone rock type class varies between 10-30\%; for siltstone rock type class varies between $25-60 \%$; for mudstone rock type class varies between $40-60 \%$ and for carbonate-cemented sandstone rock type class is less than $10 \%$. Hence, each rock type class has a distinct range of clay mineral content, which adds another unique and significant criteria to the rock type classification.

Rock type classes were further constrained in terms of the modal grain size class for each rock type. Given the variability in the modal grain size distribution, the most recurring modal grain size among samples of the same rock type has been chosen to differentiate one rock type class from the other. The coarse sandstone rock type class has the largest grain size with the most recurring modal grain size class being $0.40-0.45 \mathrm{~mm}$. The fine sandstone class has the second highest grain size values 
with the most recurring modal grain size class being $0.08-0.09 \mathrm{~mm}$. Siltstone and mudstone both have the most recurring modal grain size classes smaller than $0.01 \mathrm{~mm}$. Though modal grain size classes of siltstone and mudstone are both $<0.01 \mathrm{~mm}$, the siltstones have a bimodal distribution while mudstones strictly have only one dominant grain size class (Appendix D). The carbonate-cemented sandstone has the modal grain size class of $0.07-0.08 \mathrm{~mm}$.

Table 2. Mean mineral composition and standard deviations the five rock type classes based on QEMSCAN data. The mean is based on the data from 5 samples for rock type 1,13 samples for rock type 2, 4 samples for rock type 3, 7 samples for rock type 4 and 1 sample for rock type 5 .

\begin{tabular}{ccccccccccc}
\hline \multirow{2}{*}{ Minerals } & \multicolumn{2}{c}{ Rock Type 1 } & \multicolumn{2}{c}{ Rock Type 2 } & \multicolumn{2}{c}{ Rock Type 3 } & \multicolumn{2}{c}{ Rock Type 4 } & \multicolumn{2}{c}{ Rock Type 5 } \\
\cline { 2 - 10 } & Mean & SD & Mean & SD & Mean & SD & Mean & SD & Mean & SD \\
\hline Quartz & 0.783 & $8.13 \%$ & 0.7201 & $6.24 \%$ & 0.5275 & $13.50 \%$ & 0.3508 & $5.29 \%$ & 0.6917 & $0.00 \%$ \\
Alkali Feldspar & 0.076 & $3.40 \%$ & 0.0654 & $1.01 \%$ & 0.0591 & $0.57 \%$ & 0.0691 & $1.53 \%$ & 0.0512 & $0.00 \%$ \\
Kaolinite & 0.0415 & $1.52 \%$ & 0.0466 & $1.67 \%$ & 0.1237 & $7.04 \%$ & 0.1539 & $3.19 \%$ & 0.0331 & $0.00 \%$ \\
Smectites & 0.0334 & $2.51 \%$ & 0.045 & $2.36 \%$ & 0.1014 & $3.74 \%$ & 0.1368 & $2.83 \%$ & 0.0145 & $0.00 \%$ \\
Chlorite & 0.0233 & $0.89 \%$ & 0.0515 & $2.64 \%$ & 0.0599 & $0.19 \%$ & 0.09 & $1.51 \%$ & 0.0144 & $0.00 \%$ \\
Illite & 0.0086 & $0.57 \%$ & 0.0214 & $0.65 \%$ & 0.0437 & $1.98 \%$ & 0.0824 & $1.37 \%$ & 0.0099 & $0.00 \%$ \\
Magnesite & 0.006 & $0.32 \%$ & 0.0056 & $0.27 \%$ & 0.0098 & $0.33 \%$ & 0.018 & $0.99 \%$ & 0.0172 & $0.00 \%$ \\
Siderite & 0.0001 & $0.01 \%$ & 0.0011 & $0.23 \%$ & 0.001 & $0.06 \%$ & 0.0039 & $0.51 \%$ & 0.0001 & $0.00 \%$ \\
Ankerite & 0.0019 & $0.23 \%$ & 0.0013 & $0.46 \%$ & 0 & $0.00 \%$ & 0 & $0.00 \%$ & 0.0992 & $0.00 \%$ \\
Calcite & 0 & $0.00 \%$ & 0 & $0.01 \%$ & 0 & $0.00 \%$ & 0 & $0.00 \%$ & 0.0008 & $0.00 \%$ \\
Dolomite & 0.0004 & $0.04 \%$ & 0.0003 & $0.09 \%$ & 0 & $0.00 \%$ & 0 & $0.00 \%$ & 0.0206 & $0.00 \%$ \\
Plagioclase & 0.0121 & $0.45 \%$ & 0.0195 & $0.64 \%$ & 0.0262 & $0.60 \%$ & 0.0254 & $0.60 \%$ & 0.0186 & $0.00 \%$ \\
Muscovite & 0.009 & $0.69 \%$ & 0.0127 & $0.50 \%$ & 0.0321 & $2.21 \%$ & 0.0517 & $1.69 \%$ & 0.0108 & $0.00 \%$ \\
Pyrite & 0.0026 & $0.16 \%$ & 0.0014 & $0.10 \%$ & 0.0094 & $1.33 \%$ & 0.0138 & $1.55 \%$ & 0.0001 & $0.00 \%$ \\
Pyrophyllite & 0.0007 & $0.04 \%$ & 0.0004 & $0.03 \%$ & 0.0016 & $0.08 \%$ & 0.0009 & $0.03 \%$ & 0.0004 & $0.00 \%$ \\
Ilmenite & 0.0006 & $0.06 \%$ & 0.0025 & $0.10 \%$ & 0.0014 & $0.09 \%$ & 0.0006 & $0.01 \%$ & 0.0061 & $0.00 \%$ \\
Rutile & 0.0006 & $0.04 \%$ & 0.0029 & $0.11 \%$ & 0.0028 & $0.06 \%$ & 0.0023 & $0.03 \%$ & 0.0071 & $0.00 \%$ \\
Zircon & 0.0002 & $0.01 \%$ & 0.0023 & $0.36 \%$ & 0.0006 & $0.03 \%$ & 0.0004 & $0.01 \%$ & 0.0042 & $0.00 \%$ \\
\hline
\end{tabular}

Rock type classes and their representative properties are presented in Table 3. Characteristic capillary entry pressure ranges are added for each rock type class (Table 1). The given rock type names reflect relative differences in modal grain size, but do not strictly comply with the Wentworth classification for detrital sediments (1922).

Table 3. The five rock type classes along with the defining criteria of flow properties, mineral compositions and grain size distribution. \# gives the number of samples used for analysis of the respective property. Carbonate mineral \% has been derived from hyperspectral analysis while clay mineral $\%$ and modal grain size class have been derived from QEMSCAN analysis.

\begin{tabular}{ccccccc}
\hline Rock Type Name & $\begin{array}{c}\text { Porosity } \\
\text { Range } \\
\text { (fraction) }\end{array}$ & $\begin{array}{c}\text { Permeability } \\
\text { Range (mD) }\end{array}$ & $\begin{array}{c}\text { Bulk } \\
\text { Carbonate } \\
\text { Content }(\%)\end{array}$ & $\begin{array}{c}\text { Mean Bulk } \\
\text { Clay } \\
\text { Content (\%) }\end{array}$ & $\begin{array}{c}\text { Most Recurring } \\
\text { Modal Grain Size } \\
\text { Range (mm) }\end{array}$ & $\begin{array}{c}\text { Capillary } \\
\text { Entry } \\
\text { Pressure } \\
\text { (Pa) }\end{array}$ \\
\hline Coarse sandstone & $>0.25(\# 21)$ & $>1000(\# 21)$ & $<5(\# 21)$ & $5-20(\# 5)$ & $0.40-0.45(\# 5)$ & $100-1000$ \\
\hline Fine sandstone & $>0.25(\# 23)$ & $\begin{array}{c}100-1000 \\
(\# 23)\end{array}$ & $<5(\# 23)$ & $10-30(\# 13)$ & $0.08-0.09(\# 13)$ & $100-1000$ \\
\hline Siltstone & $<0.25(\# 5)$ & $10-100(\# 5)$ & $<5(\# 5)$ & $25-60(\# 4)$ & $<0.01(\# 4)$ & $1000-10000$ \\
\hline Mudstone & $<0.25(\# 21)$ & $<10(\# 21)$ & $<5(\# 21)$ & $40-60(\# 7)$ & $<0.01(\# 7)$ & $1000-10000$ \\
\hline $\begin{array}{c}\text { Carbonate-cemented } \\
\text { sandstone }\end{array}$ & $<0.25(\# 10)$ & $<10(\# 10)$ & $>5(\# 10)$ & $<10(\# 1)$ & $0.07-0.08(\# 1)$ & $10000-160000$ \\
\hline
\end{tabular}

The five rock type classes (Table 3) were assigned to the 82 classifiable core samples and their sampling depth was assigned to the respective depth in the hyperspectral and colourlith logs of CRC-3 (Table A3, Appendix B). This resulted in a 1-D distribution of rock types at discrete depths. The correlation between the rock types at discrete depths and the respective color shade in the 
colourlith $\log$ (Figures 9 and 10) validated the preliminary rock types as determined from the colourlith logs (Section 4.3). It now becomes clear that rock type 1 identified on the colourlith log is coarse sandstone, rock type 2 is fine sandstone, rock type 3 is siltstone, rock type 4 is mudstone and rock type 5 is carbonate-cemented sandstone. Based on the colourlith logs, the vertical variation of the five rock type classes and their respective properties is obtained at a resolution of $10 \mathrm{~cm}$.

\subsection{Correlation of Hyperspectral, ECS and Colourlith Logs}

Hyperspectral, ECS and colourlith logs for the CRC-3 well were compared to each other to investigate the robustness of the different approaches and report any inconsistencies in the output obtained from the respective techniques. The hyperspectral log in Figure 8a shows clay dominated intervals between the depths of 1461 and $1475 \mathrm{~m}$ and between 1520 and $1530 \mathrm{~m}$ which is reflected in the colourlith output where the same intervals are dominated by mudstone. The ECS log in the same intervals shows a higher proportion of clay. The hyperspectral log shows a framework dominated interval between 1475 and $1480 \mathrm{~m}$. This observation is again reflected in colourlith and the ECS log which show higher proportions of coarse sandstone and quartz, respectively, in the same interval. The hyperspectral log shows six intervals strongly enriched in carbonate, namely between the depths of 1480 and $1482 \mathrm{~m}, 1508$ and $1509 \mathrm{~m}, 1514$ and $1515 \mathrm{~m}, 1532$ and $1533 \mathrm{~m}, 1547$ and $1549 \mathrm{~m}$ and 1556 and $1558 \mathrm{~m}$. These intervals are dominated by carbonate-cemented sandstone in the colourlith $\log$ and show a small proportion of carbonates in the ECS log. The correlation is also tested for the framework and clay intercalated intervals on the hyperspectral log between the depths of 1483 and $1498 \mathrm{~m}, 1535$ and $1545 \mathrm{~m}$ and 1548 and $1555 \mathrm{~m}$. The respective intervals show hues of red, purple and blue on the colourlith log indicating the intercalation of coarse sandstone, fine sandstone and mudstone. These intervals are expected to be lithologically heterogeneous and consist of intraformational baffles. This information is difficult to deduce from the ECS log. Additionally, the colourlith identifies thin carbonate-rich sequences that do not seem to be pictured in the ECS log.

Overall, the distribution of lithology on the three logs agrees very well. Our approach to use three independent data sets for the characterization of a heterogeneous sedimentary reservoir is successful.

\subsection{Rock Type Abundance and Variability}

The colourlith logs (Figures 9 and 10) are compared to the facies logs (Figure 2) for CRC-2 and CRC-3 to obtain the abundance of different rock types within the four sedimentary facies (Figure 11). The rock type abundances are found to be similar for the two wells. The abundance of the rock types in different facies shows a relationship with the characteristic energy of the depositional environments. Coarse sandstone and fine sandstone constitute more than $50 \%$ of distributary channel and proximal mouthbar. The abundance of coarse sandstone decreases from distributary channel to proximal mouthbar and reduces to a nil in distal mouthbar and delta front facies. The proportion of siltstone and mudstone increases subsequently in the facies deposited under low energy conditions. Volumetrically, siltstone and mudstone together account for more than $70 \%$ of distal mouthbar and more than $90 \%$ of delta front facies.

Cross-well correlation gives the lateral variability of the rock types (Figures 9 and 10). The high energy facies terminate between the two wells [22] and, hence, limit the lateral extent of the constituent rock types. The vertical variability of rock types is given in terms of the range of their bed thickness in the two wells (Figure 12). The bed thickness for a given rock type is seen to vary for different facies. The facies deposited under higher energy conditions like distributary channel and proximal mouth bar show greater thickness of rock types characterized by larger grain sizes such as coarse sandstone and fine sandstone. Coarse sandstone makes the bulk of the high energy facies and its bedding thickness ranges between $20 \mathrm{~cm}$ to $3.5 \mathrm{~m}$ in distributary channel and between $20 \mathrm{~cm}$ to $2.8 \mathrm{~m}$ in proximal mouthbar (Figure 12a,b). The thickness of siltstone and mudstone is higher in low energy facies and varies between $20 \mathrm{~cm}$ to $1.5 \mathrm{~m}$ in distal mouthbar and between $20 \mathrm{~cm}$ and $1 \mathrm{~m}$ in delta front (Figure 12c,d). 


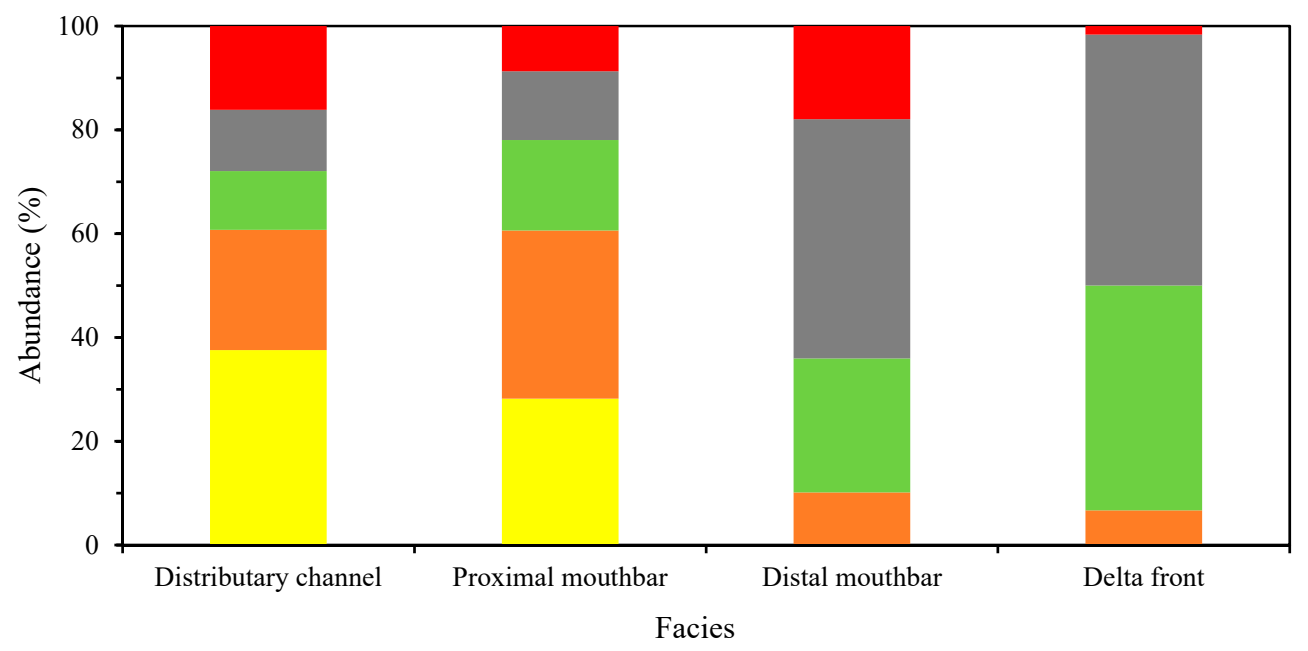

Coarse sandstone $\square$ Fine sandstone $\quad$ Siltstone $\square$ Mudstone $\square$ Carbonate-cemented sandstone

Figure 11. Abundance of the five rock type classes in the four depositional facies.

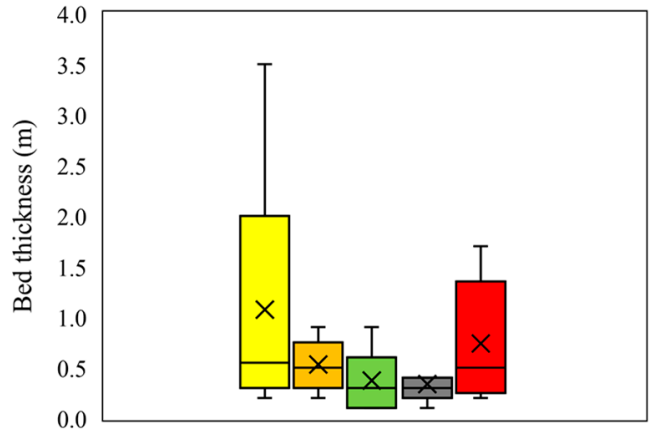

(a)

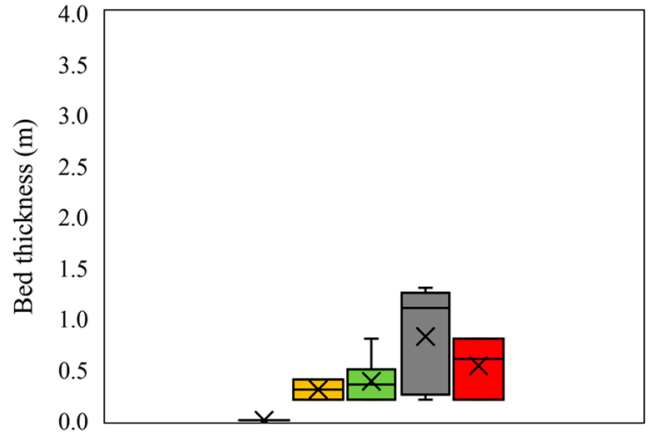

(c)

Coarse sandstone

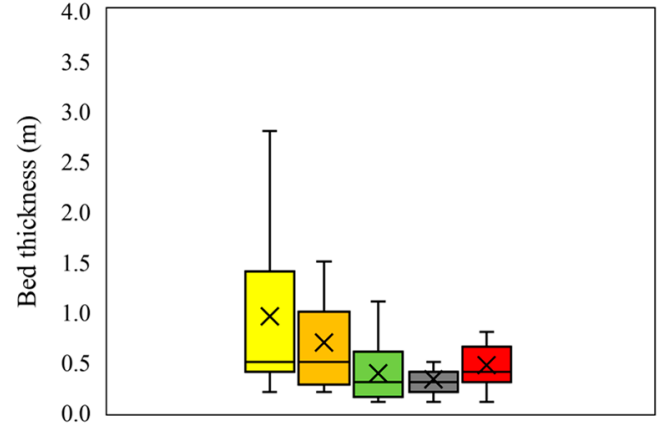

(b)

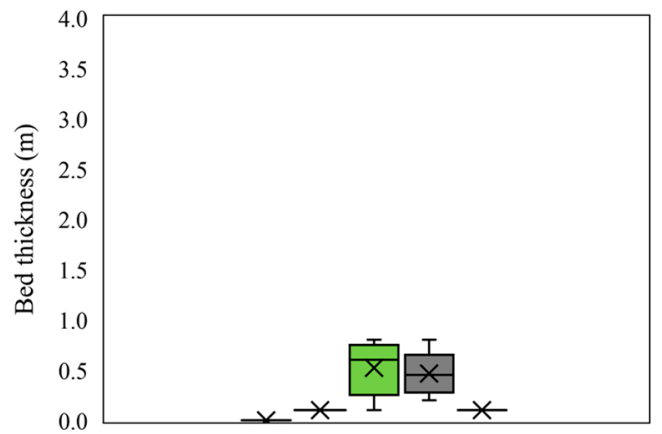

(d)

Figure 12. Range of bed thickness of the five rock types in (a) Distributary channel; (b) Proximal mouthbar; (c) Distal mouthbar; (d) Delta front. Box-and-whisker plots show mean (cross within the box), median (bar within the box), 25th and 75th quartile (lower and upper boundary of the box) and lower and upper limit of the data range (ends of the whisker).

\subsection{Implications of High Resolution Rock Typing}

The vertical distribution of rock types, their cross-well correlation and abundance in different facies has important implications. The cross-well correlation of rock properties adds significant details to the already existing facies correlation between the wells (Figure 2). As already discussed, the $\mathrm{cm}$ to meter scale heterogeneity plays an important role in fluid flow and geochemical reactions $[4,5,7-10]$. 
In coarse gridded geostatistical models, the geometry of geobodies is usually determined by using data from analogue sites in order to better constrain the geological model [55]. However, such an approach may not always be accurate. In the absence of analogue data, lithological properties are usually populated using variograms based on wireline logs. Such an approach may be impractical in reservoir models populated with large number of rock properties as variograms are required as an input for each property [3]. The independent population of different properties might also result in some grid cells with an unrealistic combination of various flow and petrophysical properties. Also, this approach is not suitable for populating mineral data into the geostatistical model. The high resolution rock typing presented in this study overcomes these challenges by using abundant data from two closely spaced wells. By coupling different flow, petrophysical and mineralogical properties in one rock type class, the number of variograms reduces to just one for each rock type class. The quantitative estimates of lateral and vertical variability of rock types and their abundance in different facies is useful in building better informed variograms as well as a more confident determination of the geometry of the geobodies. The variograms can then be used to populate coarse and fine sandstones in reservoir and siltstone and mudstone in seals based on the abundance of each rock type in each facies. Ultimately this improves the accuracy of reservoir models. The rock type classes and their correlation is useful in constructing high resolution and more confident accurate geostatic models which will consequently contribute towards improving dynamic simulation results and perhaps our understanding of the results.

\section{Conclusions}

The lowermost two parasequences of the Paaratte Formation Unit A, composed of coastal to shallow-marine sediments were used to derive a rock type classification scheme accounting for porosity and permeability, mineral composition and grain size distribution. All properties presented in this work are statistically distinct for each rock type class. The fact that the properties are derived from real samples while honoring concepts of depositional environments makes the presented rock type characterization practical and geologically consistent. The scheme can be further improved by including properties like relative permeability-saturation curves, capillary pressure-saturation curves and reactive mineral surface areas for each rock type. A major advantage of the rock typing presented here is that it meaningfully integrates the available flow, petrophysical and mineralogical properties. The rock type correlation between wells presents a high resolution extent of lithological heterogeneity vertically as well as laterally for the CO2CRC's Otway Research Facility. The results uniquely provide a fine scale structural framework for running detailed simulations addressing $\mathrm{CO}_{2}$ flow and reactions. The correlation serves to ascertain the extent and geometry of geobodies which is important information for constructing the variograms in geostatistical modelling. The work presented in this study shall contribute to the existing geostatistical models of the CO2CRC's Otway Research Facility and may support geostatic modelling at other sites composed of coastal to shallow-marine sediments as well for the purpose of flow and reactive transport simulations.

Author Contributions: Conceptualization, R.R.H.; Data curation, A.M. and L.P.; Formal analysis, A.M. and L.P.; Funding acquisition, R.R.H.; Supervision, R.R.H.; Writing-original draft, A.M. and L.P.

Funding: This research was funded by BHP Billiton.

Acknowledgments: This study is a contribution to GeoCquest, a BHP-supported collaborative project of The University of Melbourne (Australia), the University of Cambridge (UK) and Stanford University (USA), aimed at developing a better understanding of small-scale heterogeneity and its influence on $\mathrm{CO}_{2}$ trapping mechanisms. The authors would like to thank the CO2CRC Ltd. for giving access to data from the CO2CRC's Otway Research Facility and BHP for providing project funding. The authors also thank Tess Dance from CSIRO for helping to compile the data, for providing core descriptions including facies interpretations of CRC-3 and for discussing the data. The authors thank Jay Black for conducting the grain size analysis on 2D mineral maps, a service provided through the Trace Analysis for Chemical, Earth and Environmental Sciences (TrACEES) platform, which receives funding from the Melbourne Collaborative Research Infrastructure Program (MCRIP) at the University of Melbourne. The Geological Survey of Western Australia in Perth provided the hyperspectral core logging for CRC-3. QEMSCAN analysis was done at the Centre for Advanced Microscopy, Australian National University.

Conflicts of Interest: The authors declare no conflict of interest. 


\section{Appendix A}

This section presents the 30 core samples chosen for QEMSCAN and grain size analysis. The samples cover the range of lithological heterogeneity found in the different sedimentary facies. Table A1 provides a description of depth, depositional environment and all available flow data. Sample IDs are marked on the samples.
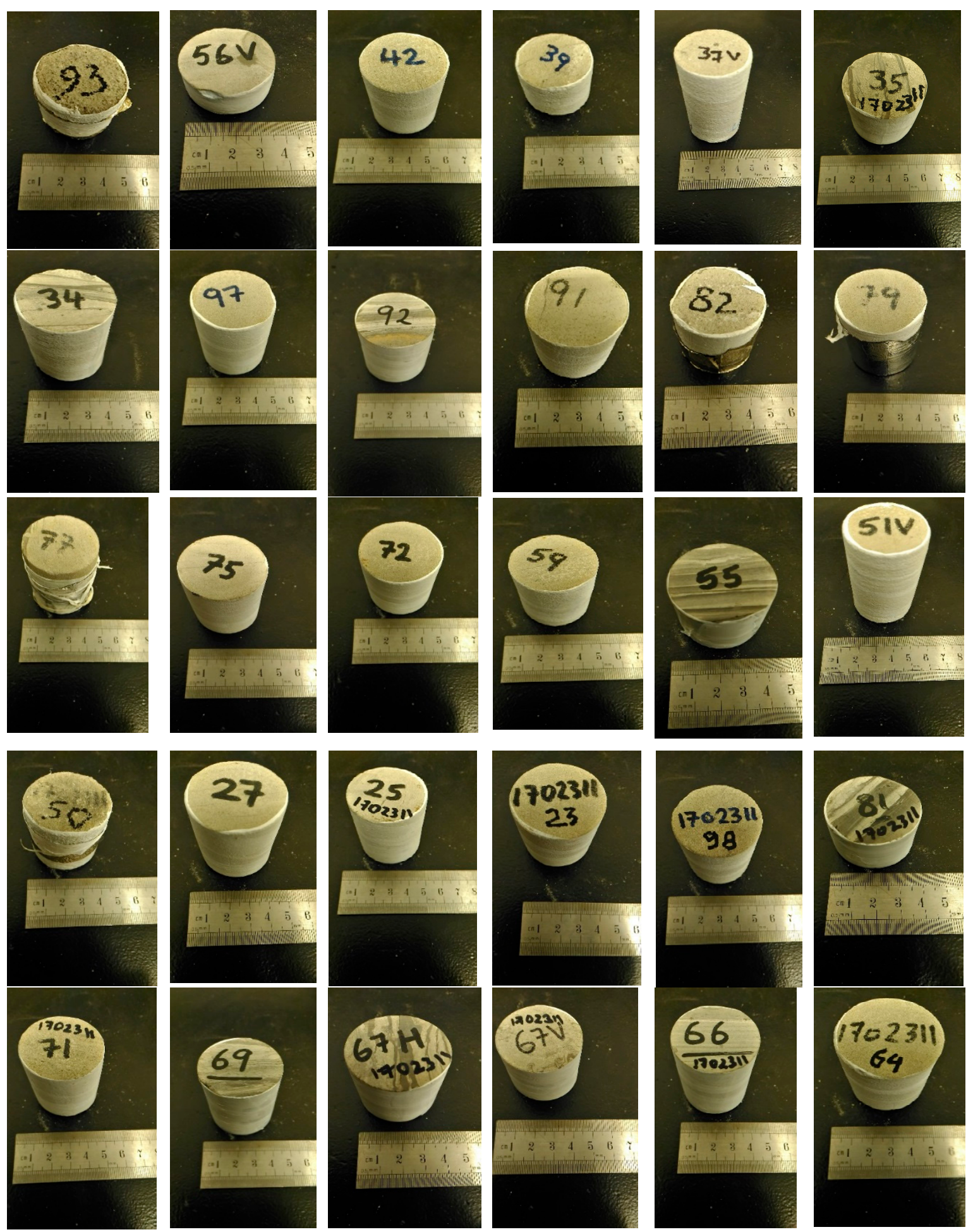

Figure A1. The core samples chosen for quantitative mineral analysis. 
Table A1. 30 core samples from CRC-3 well.

\begin{tabular}{|c|c|c|c|c|}
\hline $\begin{array}{l}\text { Sedimentary } \\
\text { Facies }\end{array}$ & Core Sample ID & Sample Depth (m) & Porosity (\%) & Permeability (mD) \\
\hline \multirow{7}{*}{$\begin{array}{c}\text { Distributary } \\
\text { Channel }\end{array}$} & \#93 & 1477.20 & 26.9 & 7410.00 \\
\hline & \#56V & 1533.78 & 21.2 & 1.07 \\
\hline & $\# 42$ & 1549.75 & 28.4 & 1110.00 \\
\hline & \#39 & 1551.25 & 26.5 & 615.00 \\
\hline & \#37V & 1552.82 & 29.6 & 1930.00 \\
\hline & \#35 & 1553.48 & 21.2 & 130.00 \\
\hline & $\# 34$ & 1554.07 & 16.4 & 27.50 \\
\hline \multirow{15}{*}{$\begin{array}{l}\text { Proximal } \\
\text { Mouthbar }\end{array}$} & \#97 & 1464.80 & 28.5 & 141.00 \\
\hline & $\# 92$ & 1481.55 & 13.1 & 0.55 \\
\hline & \#91 & 1484.45 & 29.7 & 1010.00 \\
\hline & $\# 82$ & 1502.90 & 24.0 & 357.00 \\
\hline & $\# 79$ & 1506.92 & 29.3 & 262.00 \\
\hline & \#77 & 1508.80 & 26.6 & 353.00 \\
\hline & $\# 75$ & 1513.60 & 23.4 & 198.00 \\
\hline & $\# 72$ & 1518.45 & 27.1 & 109.00 \\
\hline & \#59 & 1531.50 & 29.0 & 357.00 \\
\hline & \#55 & 1533.86 & 12.6 & 33.40 \\
\hline & \#51V & 1539.50 & 26.8 & 407.00 \\
\hline & \#50 & 1540.30 & 28.3 & 4160.00 \\
\hline & $\# 27$ & 1560.95 & 28.0 & 249.00 \\
\hline & $\# 25$ & 1562.60 & 22.7 & 17.00 \\
\hline & $\# 23$ & 1563.60 & 29.1 & 535.00 \\
\hline \multirow{2}{*}{ Distal Mouthbar } & \#98 & 1462.85 & 28.8 & 324.00 \\
\hline & $\# 81$ & 1505.00 & 14.1 & 0.90 \\
\hline \multirow{6}{*}{ Delta Front } & $\# 71$ & 1520.50 & 28.4 & 182.00 \\
\hline & \#69 & 1523.90 & 17.2 & 0.08 \\
\hline & $\# 67 \mathrm{H}$ & 1524.65 & 21.5 & 0.64 \\
\hline & \#67V & 1524.65 & 21.5 & NA \\
\hline & \#66 & 1525.64 & 16.3 & 0.47 \\
\hline & $\# 64$ & 1526.05 & 27.6 & 268.00 \\
\hline
\end{tabular}

\section{Appendix B}

The following section presents the samples assigned to the five rock type classes (Table A2) and the analysis of Hylogger data (Table A3).

Table A2. 30 samples chosen for QEMSCAN analysis as assigned to different rock type classes.

\begin{tabular}{ll}
\hline \multicolumn{1}{c}{ Rock Type Classes } & \multicolumn{1}{c}{ Sample ID for QEMSCAN Analysis } \\
\hline Rock Type 1 (Coarse Sandstone) & $\# 93, \# 50, \# 37 \mathrm{~V}, \# 42, \# 91$ \\
Rock Type 2 (Fine Sandstone) & $\# 23, \# 27, \# 39, \# 51, \# 64, \# 71, \# 72, \# 79, \# 82, \# 98, \# 59, \# 97, \# 77$ \\
Rock Type 3 (Siltstone) & $\# 25, \# 34, \# 35, \# 55$ \\
Rock Type 4 (Mudstone) & $\# 56 \mathrm{~V}, \# 66, \# 67 \mathrm{~V}, \# 69, \# 81, \# 92, \# 67 \mathrm{H}$ \\
Rock Type 5 & $\# 75$ \\
(Carbonate-cemented Sandstone) & \\
\hline
\end{tabular}


Table A3. Hylogger data from CRC-3 well and corresponding rocktype classes.

\begin{tabular}{|c|c|c|c|c|c|c|}
\hline \multicolumn{2}{|c|}{ Distributary channel } & \multicolumn{2}{|c|}{ Proximal mouthbar } & \multicolumn{2}{|c|}{ Distal mouthbar } & \multirow{2}{*}{$\begin{array}{c}\text { Delta front } \\
\text { Rock Type Class Assigned }\end{array}$} \\
\hline Depth (m) & $\begin{array}{c}\text { Porosity } \\
\text { (Fraction) }\end{array}$ & $\begin{array}{l}\text { Permeability } \\
\text { (mD) }\end{array}$ & $\begin{array}{c}\text { Framework } \\
(\%)\end{array}$ & Clay (\%) & $\begin{array}{c}\text { Carbonate } \\
(\%)\end{array}$ & \\
\hline 1462.85 & 0.29 & 324.00 & 78.47 & 0.00 & 21.53 & Carbonate-cemented sandstone \\
\hline 1464.80 & 0.29 & 141.00 & 86.91 & 9.53 & 3.56 & Fine sandstone \\
\hline 1466.80 & 0.20 & 1.03 & 62.66 & 18.56 & 18.78 & Carbonate-cemented sandstone \\
\hline 1470.80 & 0.20 & 2.25 & 83.66 & 16.34 & 0.00 & Mudstone \\
\hline 1474.55 & 0.15 & 0.06 & 74.83 & 18.40 & 6.77 & Carbonate-cemented sandstone \\
\hline 1477.20 & 0.27 & 7410.00 & 100.00 & 0.00 & 0.00 & Coarse sandstone \\
\hline 1481.55 & 0.13 & 0.55 & 76.10 & 0.00 & 23.90 & Carbonate-cemented sandstone \\
\hline 1484.45 & 0.31 & 4930.00 & 100.00 & 0.00 & 0.00 & Coarse sandstone \\
\hline 1484.45 & 0.30 & 1010.00 & 100.00 & 0.00 & 0.00 & Coarse sandstone \\
\hline 1488.70 & 0.23 & 10300.00 & 100.00 & 0.00 & 0.00 & Coarse sandstone ${ }^{*}$ \\
\hline 1492.64 & 0.29 & 2810.00 & 100.00 & 0.00 & 0.00 & Coarse sandstone \\
\hline 1495.90 & 0.28 & 2040.00 & 100.00 & 0.00 & 0.00 & Coarse sandstone \\
\hline 1499.03 & 0.26 & 19.60 & 100.00 & 0.00 & 0.00 & Unclassified \\
\hline 1499.10 & 0.28 & 747.00 & 100.00 & 0.00 & 0.00 & Fine sandstone \\
\hline 1499.40 & 0.30 & 1140.00 & 81.74 & 8.73 & 9.53 & Carbonate-cemented sandstone \\
\hline 1501.00 & 0.13 & 0.83 & 59.60 & 3.65 & 36.75 & Carbonate-cemented sandstone \\
\hline 1502.90 & 0.24 & 357.00 & 100.00 & 0.00 & 0.00 & Fine sandstone ${ }^{*}$ \\
\hline 1505.00 & 0.14 & 0.90 & 88.94 & 4.46 & 6.60 & Carbonate-cemented sandstone \\
\hline 1505.85 & 0.19 & 1.46 & 97.21 & 2.79 & 0.00 & Mudstone \\
\hline 1506.92 & 0.29 & 262.00 & 100.00 & 0.00 & 0.00 & Fine sandstone \\
\hline 1508.12 & 0.29 & 476.00 & 100.00 & 0.00 & 0.00 & Fine sandstone \\
\hline 1508.80 & 0.27 & 353.00 & 100.00 & 0.00 & 0.00 & Fine sandstone \\
\hline 1510.75 & 0.21 & 2.82 & 63.99 & 33.52 & 2.50 & Mudstone \\
\hline 1513.60 & 0.23 & 198.00 & 92.75 & 0.00 & 7.25 & Carbonate-cemented sandstone \\
\hline 1516.65 & 0.19 & 6.35 & 76.89 & 23.11 & 0.00 & Mudstone \\
\hline 1517.80 & 0.29 & 205.00 & 95.03 & 3.23 & 1.74 & Fine sandstone \\
\hline 1518.45 & 0.27 & 109.00 & 92.39 & 7.61 & 0.00 & Fine sandstone \\
\hline 1522.75 & 0.15 & 0.02 & 63.96 & 36.04 & 0.00 & Mudstone * \\
\hline 1523.90 & 0.17 & 0.08 & 76.62 & 23.38 & 0.00 & Mudstone * \\
\hline 1524.60 & 0.19 & 0.55 & 77.62 & 22.38 & 0.00 & Mudstone ${ }^{*}$ \\
\hline 1524.65 & 0.22 & 0.64 & 85.38 & 14.62 & 0.00 & Mudstone * \\
\hline 1525.64 & 0.16 & 0.47 & 78.63 & 21.37 & 0.00 & Mudstone * \\
\hline 1526.05 & 0.28 & 268.00 & 91.46 & 8.54 & 0.00 & Fine sandstone \\
\hline 1526.25 & 0.15 & 0.16 & 70.08 & 29.92 & 0.00 & Mudstone ${ }^{*}$ \\
\hline 1526.80 & 0.15 & 0.03 & 63.21 & 36.79 & 0.00 & Mudstone * \\
\hline 1528.50 & 0.16 & 0.05 & 60.47 & 39.53 & 0.00 & Mudstone * \\
\hline 1528.53 & 0.16 & 0.03 & 60.47 & 39.53 & 0.00 & Mudstone * \\
\hline 1529.60 & 0.27 & 751.00 & 92.60 & 0.00 & 7.40 & Carbonate-cemented sandstone \\
\hline 1529.65 & 0.27 & 814.00 & 100.00 & 0.00 & 0.00 & Fine sandstone \\
\hline 1529.70 & 0.26 & 373.00 & 100.00 & 0.00 & 0.00 & Fine sandstone \\
\hline 1531.50 & 0.29 & 357.00 & 94.40 & 5.60 & 0.00 & Fine sandstone \\
\hline 1532.85 & 0.16 & 7.14 & 92.64 & 7.36 & 0.00 & Mudstone \\
\hline 1533.23 & 0.28 & 1200.00 & 96.24 & 3.76 & 0.00 & Coarse sandstone \\
\hline 1533.78 & 0.21 & 1.07 & 74.24 & 25.76 & 0.00 & Mudstone \\
\hline 1533.86 & 0.13 & 33.40 & 61.99 & 38.01 & 0.00 & Siltstone \\
\hline 1534.10 & 0.23 & 15.30 & 87.31 & 12.69 & 0.00 & Siltstone \\
\hline 1534.82 & 0.12 & 0.15 & 71.41 & 28.59 & 0.00 & Mudstone \\
\hline 1539.50 & 0.27 & 407.00 & 100.00 & 0.00 & 0.00 & Fine sandstone \\
\hline 1539.60 & 0.28 & 1190.00 & 100.00 & 0.00 & 0.00 & Coarse sandstone \\
\hline 1540.30 & 0.28 & 4160.00 & 100.00 & 0.00 & 0.00 & Coarse sandstone \\
\hline 1540.55 & 0.29 & 1820.00 & 100.00 & 0.00 & 0.00 & Coarse sandstone \\
\hline 1541.35 & 0.29 & 2200.00 & 100.00 & 0.00 & 0.00 & Coarse sandstone \\
\hline 1542.35 & 0.30 & 2010.00 & 100.00 & 0.00 & 0.00 & Coarse sandstone \\
\hline 1542.42 & 0.30 & 2410.00 & 100.00 & 0.00 & 0.00 & Coarse sandstone \\
\hline 1543.75 & 0.28 & 2380.00 & 100.00 & 0.00 & 0.00 & Coarse sandstone \\
\hline 1548.90 & 0.02 & 0.02 & 74.25 & 0.00 & 25.75 & Carbonate-cemented sandstone \\
\hline 1549.25 & 0.17 & 1.05 & 82.93 & 17.07 & 0.00 & Mudstone \\
\hline 1549.75 & 0.28 & 1110.00 & 98.43 & 0.00 & 1.57 & Coarse sandstone \\
\hline 1550.30 & 0.28 & 799.00 & 100.00 & 0.00 & 0.00 & Fine sandstone \\
\hline 1550.75 & 0.23 & 1030.00 & 67.68 & 32.32 & 0.00 & Unclassified \\
\hline 1551.25 & 0.27 & 615.00 & 96.91 & 3.09 & 0.00 & Fine sandstone \\
\hline 1551.65 & 0.24 & 9670.00 & 97.44 & 0.00 & 2.56 & Coarse sandstone ${ }^{*}$ \\
\hline
\end{tabular}


Table A3. Cont.

\begin{tabular}{|c|c|c|c|c|c|c|}
\hline \multicolumn{2}{|c|}{ Distributary channel } & \multicolumn{2}{|c|}{ Proximal mouthbar } & \multicolumn{2}{|c|}{ Distal mouthbar } & \multirow{2}{*}{$\begin{array}{c}\text { Delta front } \\
\text { Rock Type Class Assigned }\end{array}$} \\
\hline Depth (m) & $\begin{array}{l}\text { Porosity } \\
\text { (Fraction) }\end{array}$ & $\begin{array}{l}\text { Permeability } \\
\text { (mD) }\end{array}$ & $\begin{array}{c}\text { Framework } \\
(\%)\end{array}$ & Clay (\%) & $\begin{array}{c}\text { Carbonate } \\
(\%)\end{array}$ & \\
\hline 1552.82 & 0.30 & 1930.00 & 100.00 & 0.00 & 0.00 & Coarse sandstone \\
\hline 1552.95 & 0.30 & 2550.00 & 100.00 & 0.00 & 0.00 & Coarse sandstone \\
\hline 1553.48 & 0.21 & 130.00 & 74.71 & 25.29 & 0.00 & Siltstone ${ }^{*}$ \\
\hline 1554.07 & 0.16 & 27.50 & 67.75 & 32.25 & 0.00 & Siltstone \\
\hline 1554.12 & 0.16 & 0.03 & 67.75 & 32.25 & 0.00 & Mudstone ${ }^{*}$ \\
\hline 1554.25 & 0.27 & 5250.00 & 78.34 & 21.66 & 0.00 & Coarse sandstone \\
\hline 1555.35 & 0.30 & 2840.00 & 91.57 & 8.43 & 0.00 & Coarse sandstone \\
\hline 1556.42 & 0.29 & 556.00 & 100.00 & 0.00 & 0.00 & Fine sandstone \\
\hline 1556.55 & 0.30 & 3420.00 & 100.00 & 0.00 & 0.00 & Coarse sandstone \\
\hline 1559.57 & 0.28 & 195.00 & 89.59 & 10.41 & 0.00 & Fine sandstone \\
\hline 1560.95 & 0.28 & 249.00 & 84.83 & 15.17 & 0.00 & Fine sandstone \\
\hline 1561.02 & 0.29 & 318.00 & 100.00 & 0.00 & 0.00 & Fine sandstone \\
\hline 1562.60 & 0.23 & 17.00 & 79.38 & 20.62 & 0.00 & Siltstone \\
\hline 1562.64 & 0.28 & 89.10 & 69.62 & 30.38 & 0.00 & Fine sandstone ${ }^{*}$ \\
\hline 1563.35 & 0.29 & 380.00 & 100.00 & 0.00 & 0.00 & Fine sandstone \\
\hline 1563.45 & 0.29 & 378.00 & 86.20 & 13.80 & 0.00 & Fine sandstone \\
\hline 1563.60 & 0.29 & 535.00 & 76.04 & 23.96 & 0.00 & Fine sandstone \\
\hline 1564.25 & 0.17 & 0.57 & 63.18 & 36.82 & 0.00 & Mudstone ${ }^{*}$ \\
\hline 1564.70 & 0.22 & 3.73 & 65.05 & 34.95 & 0.00 & Mudstone \\
\hline 1565.39 & 0.17 & 0.15 & 77.95 & 22.05 & 0.00 & Mudstone ${ }^{*}$ \\
\hline
\end{tabular}

Rock type classes marked ${ }^{*}$ do not strictly fall into the porosity and permeability range defined in Table 2. 


\section{Appendix C}

\begin{tabular}{|c|c|c|}
\hline \multicolumn{3}{|c|}{ Sample ID: \#93 } \\
\hline Minerals & Area \% & Mineral map \\
\hline Alkali & & \\
\hline Feldspar & $11.14 \%$ & \\
\hline Ankerite & $0.00 \%$ & \\
\hline Calcite & $0.01 \%$ & \\
\hline Chlorite & $0.09 \%$ & \\
\hline Dolomite & $0.00 \%$ & \\
\hline Illite & $0.33 \%$ & \\
\hline Ilmenite & $0.01 \%$ & \\
\hline Kaolinite & $4.09 \%$ & \\
\hline Magnesite & $0.73 \%$ & \\
\hline Muscovite & $0.64 \%$ & \\
\hline Palygorskite & $1.68 \%$ & \\
\hline Plagioclase & $1.30 \%$ & \\
\hline Pyrite & $0.24 \%$ & \\
\hline Pyrophyllite & $0.07 \%$ & \\
\hline Quartz & $78.07 \%$ & ســ \\
\hline Rutile & $0.01 \%$ & $2 \mathrm{~mm}$ \\
\hline Siderite & $0.00 \%$ & \\
\hline Smectites & $1.58 \%$ & \\
\hline Zircon & $0.01 \%$ & \\
\hline
\end{tabular}

\begin{tabular}{|c|c|c|}
\hline \multicolumn{3}{|c|}{ Sample ID: \#56V } \\
\hline Minerals & Area \% & Mineral map \\
\hline Alkali & & \multirow{20}{*}{ 2. } \\
\hline Feldspar & $9.95 \%$ & \\
\hline Ankerite & $0.00 \%$ & \\
\hline Calcite & $0.00 \%$ & \\
\hline Chlorite & $4.13 \%$ & \\
\hline Dolomite & $0.00 \%$ & \\
\hline Illite & $6.52 \%$ & \\
\hline Ilmenite & $0.04 \%$ & \\
\hline Kaolinite & $13.57 \%$ & \\
\hline Magnesite & $1.66 \%$ & \\
\hline Muscovite & $4.46 \%$ & \\
\hline Palygorskite & $2.32 \%$ & \\
\hline Plagioclase & $2.82 \%$ & \\
\hline Pyrite & $3.95 \%$ & \\
\hline Pyrophyllite & $0.08 \%$ & \\
\hline Quartz & $39.81 \%$ & \\
\hline Rutile & $0.18 \%$ & \\
\hline Siderite & $0.25 \%$ & \\
\hline Smectites & $10.22 \%$ & \\
\hline Zircon & $0.03 \%$ & \\
\hline
\end{tabular}

\begin{tabular}{|l|r|r|}
\hline \multicolumn{3}{|c|}{ Sample ID: \#42 } \\
\hline Minerals & Area \% & Mineral map \\
\hline Alkali & & \\
Feldspar & $12.08 \%$ \\
\hline Ankerite & $0.50 \%$ \\
\hline Calcite & $0.00 \%$ \\
\hline Chlorite & $1.00 \%$ \\
\hline Dolomite & $0.09 \%$ \\
\hline Illite & $1.88 \%$ \\
\hline Ilmenite & $0.02 \%$ \\
\hline Kaolinite & $6.57 \%$ \\
\hline Magnesite & $1.03 \%$ & \\
\hline Muscovite & $2.24 \%$ \\
\hline Palygorskite & $2.47 \%$ \\
\hline Plagioclase & $1.99 \%$ & \\
\hline Pyrite & $0.54 \%$ & \\
\hline Pyrophyllite & $0.13 \%$ & \\
\hline Quartz & $64.85 \%$ & \\
\hline Rutile & $0.05 \%$ \\
\hline Siderite & $0.02 \%$ \\
\hline Smectites & $4.52 \%$ \\
\hline Zircon & $0.02 \%$ & \\
\hline
\end{tabular}

\begin{tabular}{|c|c|c|}
\hline \multicolumn{3}{|c|}{ Sample ID: \#39 } \\
\hline Minerals & Area \% & Mineral map \\
\hline Alkali & & \multirow{15}{*}{ 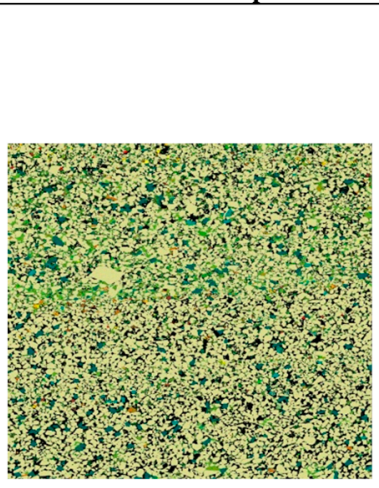 } \\
\hline Feldspar & $4.41 \%$ & \\
\hline Ankerite & $0.00 \%$ & \\
\hline Calcite & $0.00 \%$ & \\
\hline Chlorite & $0.74 \%$ & \\
\hline Dolomite & $0.00 \%$ & \\
\hline Illite & $1.26 \%$ & \\
\hline Ilmenite & $0.28 \%$ & \\
\hline Kaolinite & $5.72 \%$ & \\
\hline Magnesite & $0.40 \%$ & \\
\hline Muscovite & $0.54 \%$ & \\
\hline Palygorskite & $2.26 \%$ & \\
\hline Plagioclase & $1.12 \%$ & \\
\hline Pyrite & $0.37 \%$ & \\
\hline Pyrophyllite & $0.05 \%$ & \\
\hline Quartz & $79.82 \%$ & \multirow{5}{*}{$\underset{2 \mathrm{~mm}}{-}$} \\
\hline Rutile & $0.25 \%$ & \\
\hline Siderite & $0.01 \%$ & \\
\hline Smectites & $2.68 \%$ & \\
\hline Zircon & $0.09 \%$ & \\
\hline
\end{tabular}

Figure A2. Cont. 


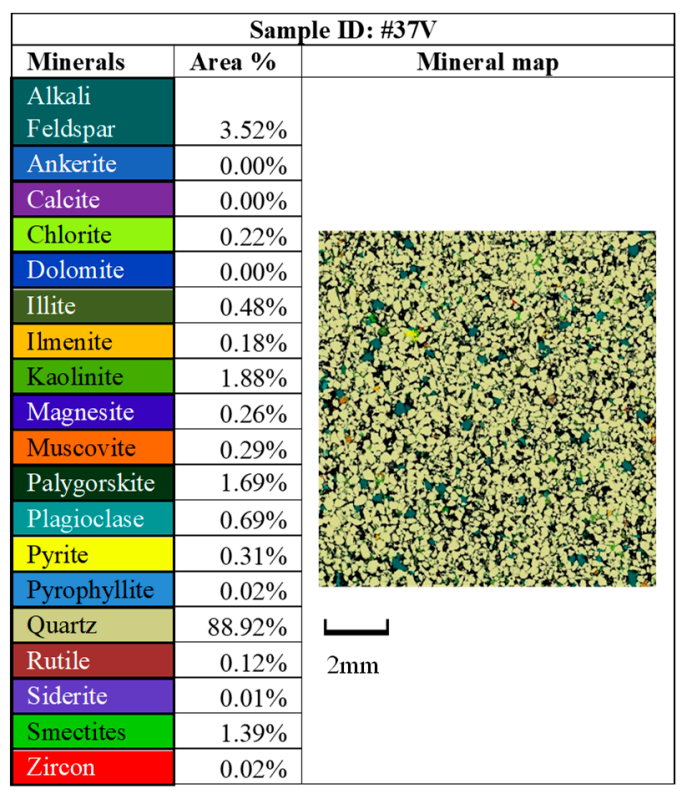

\begin{tabular}{|c|c|c|}
\hline \multicolumn{3}{|c|}{ Sample ID: \#34 } \\
\hline Minerals & Area \% & Mineral map \\
\hline Alkali & & \\
\hline Feldspar & $6.79 \%$ & \\
\hline Ankerite & $0.00 \%$ & \\
\hline Calcite & $0.00 \%$ & \\
\hline Chlorite & $1.27 \%$ & \\
\hline Dolomite & $0.00 \%$ & \\
\hline Illite & $2.49 \%$ & \\
\hline Ilmenite & $0.12 \%$ & \\
\hline Kaolinite & $6.59 \%$ & \\
\hline Magnesite & $0.74 \%$ & \\
\hline Muscovite & $1.44 \%$ & \\
\hline Palygorskite & $4.86 \%$ & \\
\hline Plagioclase & $2.83 \%$ & \\
\hline Pyrite & $0.31 \%$ & \\
\hline Pyrophyllite & $0.30 \%$ & is \\
\hline Quartz & $62.76 \%$ & \\
\hline Rutile & $0.24 \%$ & $2 \mathrm{~mm}$ \\
\hline Siderite & $0.05 \%$ & \\
\hline Smectites & $9.15 \%$ & \\
\hline Zircon & & \\
\hline
\end{tabular}

\begin{tabular}{|c|c|c|}
\hline \multicolumn{3}{|c|}{ Sample ID: $\$ 92$} \\
\hline Minerals & Area \% & Mineral map \\
\hline Alkali & & \\
\hline Feldspar & $4.94 \%$ & \\
\hline Ankerite & $0.00 \%$ & \\
\hline Calcite & $0.00 \%$ & \\
\hline Chlorite & $7.45 \%$ & \\
\hline Dolomite & $0.00 \%$ & \\
\hline Illite & $8.00 \%$ & \\
\hline Ilmenite & $0.05 \%$ & \\
\hline Kaolinite & $19.64 \%$ & \\
\hline Magnesite & $4.13 \%$ & \\
\hline Muscovite & $7.95 \%$ & \\
\hline Palygorskite & $2.18 \%$ & \\
\hline Plagioclase & $1.56 \%$ & \\
\hline Pyrite & $3.65 \%$ & \\
\hline Pyrophyllite & $0.09 \%$ & \\
\hline Quartz & $28.44 \%$ & \\
\hline Rutile & $0.26 \%$ & 2 \\
\hline Siderite & $1.62 \%$ & $2 \mathrm{~mm}$ \\
\hline Smectites & $10.00 \%$ & \\
\hline Zircon & $0.04 \%$ & \\
\hline
\end{tabular}
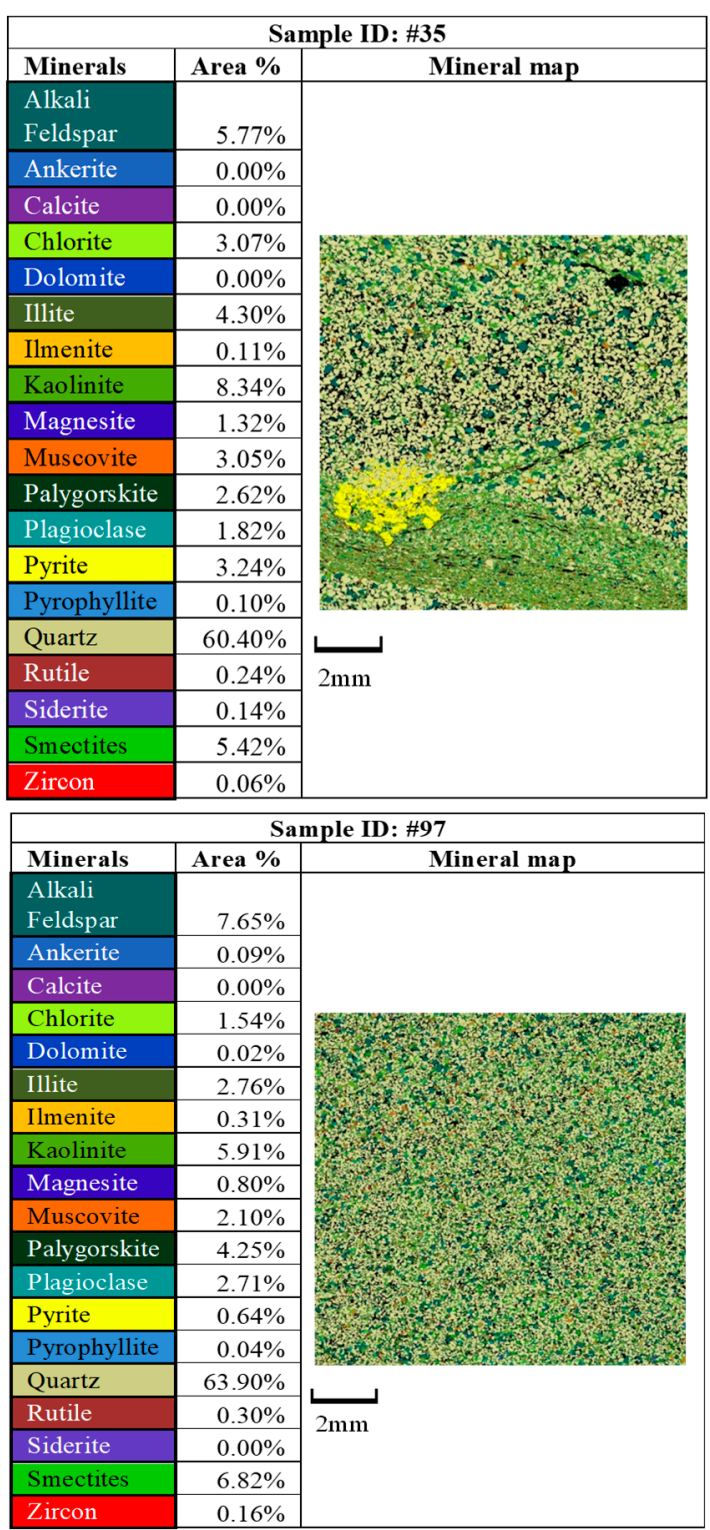

\begin{tabular}{|c|c|c|}
\hline \multicolumn{3}{|c|}{ Sample ID: \#91 } \\
\hline Minerals & Area \% & Mineral map \\
\hline Alkali & & \multirow{20}{*}{\begin{tabular}{|c|c|} 
\\
3
\end{tabular}} \\
\hline Feldspar & $4.96 \%$ & \\
\hline Ankerite & $0.00 \%$ & \\
\hline Calcite & $0.00 \%$ & \\
\hline Chlorite & $0.29 \%$ & \\
\hline Dolomite & $0.00 \%$ & \\
\hline Illite & $1.10 \%$ & \\
\hline Ilmenite & $0.05 \%$ & \\
\hline Kaolinite & $4.62 \%$ & \\
\hline Magnesite & $0.20 \%$ & \\
\hline Muscovite & $0.69 \%$ & \\
\hline Palygorskite & $3.02 \%$ & \\
\hline Plagioclase & $1.18 \%$ & \\
\hline Pyrite & $0.10 \%$ & \\
\hline Pyrophyllite & $0.04 \%$ & \\
\hline Quartz & $75.83 \%$ & \\
\hline Rutile & $0.11 \%$ & \\
\hline Siderite & $0.01 \%$ & \\
\hline Smectites & $7.77 \%$ & \\
\hline Zircon & $0.03 \%$ & \\
\hline
\end{tabular}

Figure A2. Cont. 


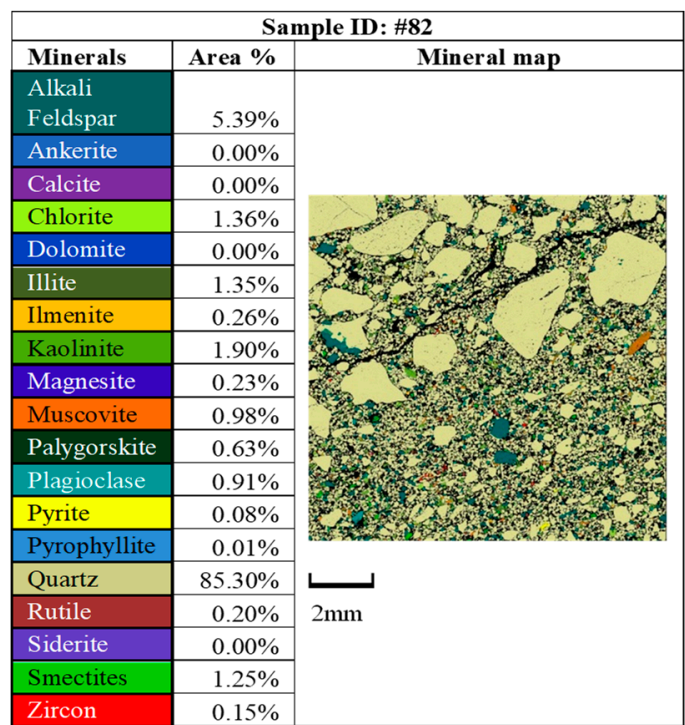

\begin{tabular}{|l|r|r|}
\hline \multicolumn{3}{|c|}{ Sample ID: \#77 } \\
\hline Minerals & Area \% & \multicolumn{1}{|c|}{ Mineral map } \\
\hline Alkali & & \\
Feldspar & $7.33 \%$ \\
\hline Ankerite & $0.00 \%$ \\
\hline Calcite & $0.00 \%$ \\
\hline Chlorite & $2.07 \%$ \\
\hline Dolomite & $0.00 \%$ & \\
\hline Illite & $3.96 \%$ \\
\hline Ilmenite & $0.07 \%$ & \\
\hline Kaolinite & $8.43 \%$ & \\
\hline Magnesite & $0.41 \%$ & \\
\hline Muscovite & $1.37 \%$ & \\
\hline Palygorskite & $6.96 \%$ & \\
\hline Plagioclase & $1.71 \%$ & \\
\hline Pyrite & $0.06 \%$ & \\
\hline Pyrophyllite & $0.05 \%$ & \\
\hline Quartz & $62.65 \%$ & \\
\hline Rutile & $0.12 \%$ & $2 \mathrm{~mm}$ \\
\hline Siderite & $0.26 \%$ \\
\hline Smectites & $4.52 \%$ \\
\hline Zircon & $0.03 \%$ & \\
\hline
\end{tabular}

\begin{tabular}{|c|c|c|}
\hline \multicolumn{3}{|c|}{ Sample ID: \#72 } \\
\hline Minerals & Area \% & Mineral map \\
\hline $\begin{array}{l}\text { Alkali } \\
\text { Feldspar }\end{array}$ & $7.58 \%$ & \multirow{19}{*}{ 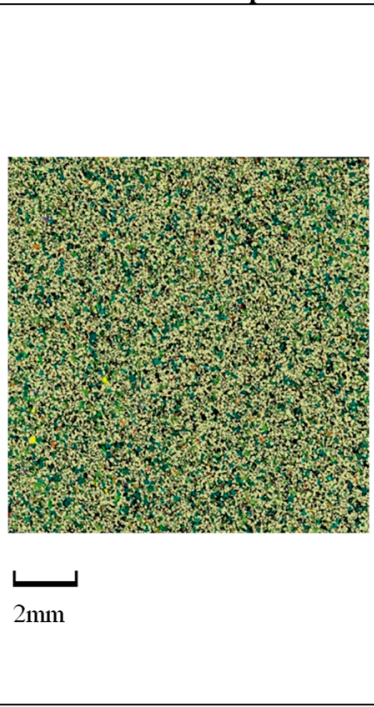 } \\
\hline Ankerite & $0.00 \%$ & \\
\hline Calcite & $0.00 \%$ & \\
\hline Chlorite & $1.59 \%$ & \\
\hline Dolomite & $0.00 \%$ & \\
\hline Illite & $1.80 \%$ & \\
\hline Ilmenite & $0.31 \%$ & \\
\hline Kaolinite & $4.38 \%$ & \\
\hline Magnesite & $0.59 \%$ & \\
\hline Muscovite & $1.37 \%$ & \\
\hline Palygorskite & $0.99 \%$ & \\
\hline Plagioclase & $2.53 \%$ & \\
\hline Pyrite & $0.11 \%$ & \\
\hline Pyrophyllite & $0.04 \%$ & \\
\hline Quartz & $75.02 \%$ & \\
\hline Rutile & $0.44 \%$ & \\
\hline Siderite & $0.29 \%$ & \\
\hline Smectites & $2.83 \%$ & \\
\hline Zircon & $0.13 \%$ & \\
\hline
\end{tabular}

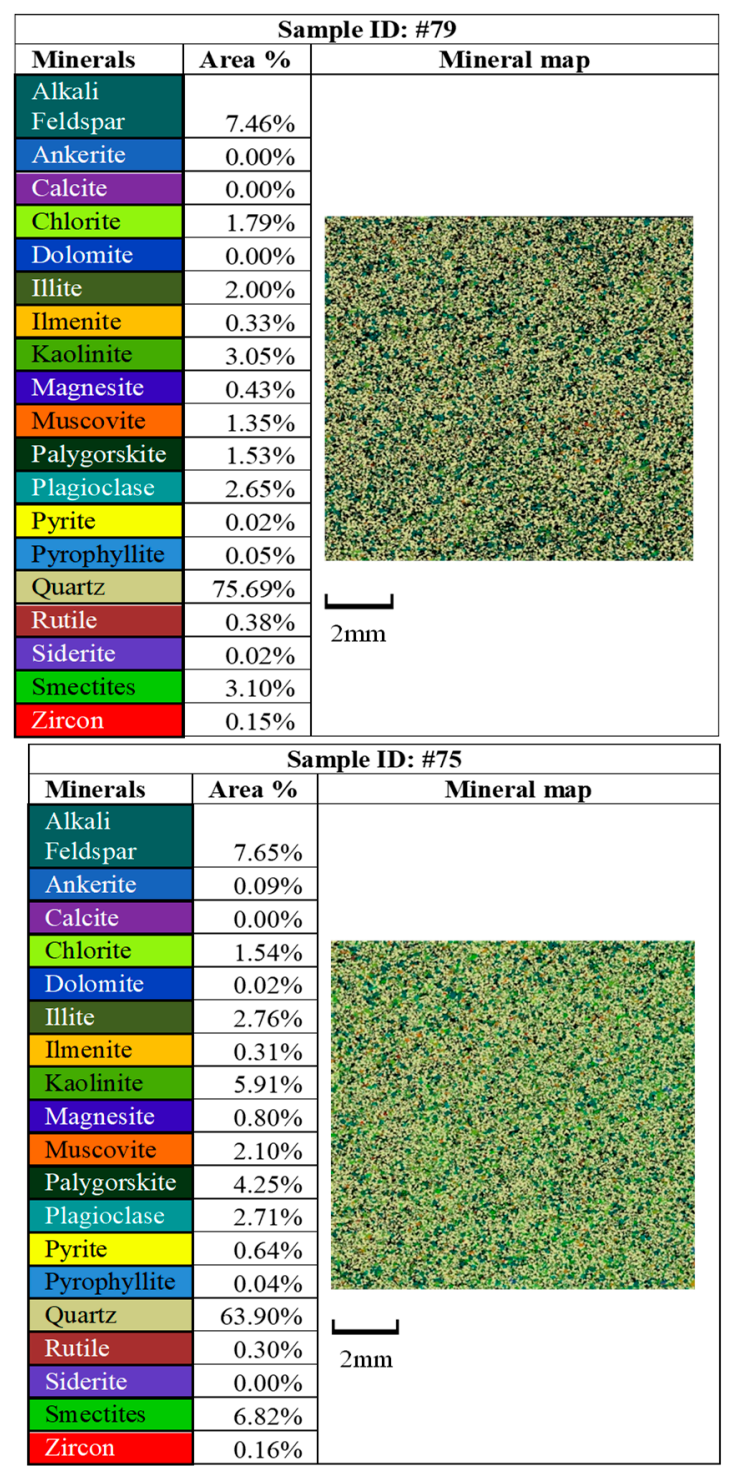

\begin{tabular}{|c|c|c|}
\hline \multicolumn{3}{|c|}{ Sample ID: \#59 } \\
\hline Minerals & Area \% & Mineral map \\
\hline Alkali & & \multirow{15}{*}{ 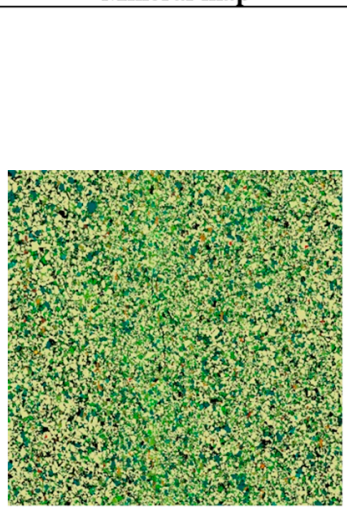 } \\
\hline Feldspar & $5.89 \%$ & \\
\hline Ankerite & $0.00 \%$ & \\
\hline Calcite & $0.00 \%$ & \\
\hline Chlorite & $1.02 \%$ & \\
\hline Dolomite & $0.00 \%$ & \\
\hline Illite & $2.33 \%$ & \\
\hline Ilmenite & $0.27 \%$ & \\
\hline Kaolinite & $8.14 \%$ & \\
\hline Magnesite & $0.40 \%$ & \\
\hline Muscovite & $1.09 \%$ & \\
\hline Palygorskite & $3.26 \%$ & \\
\hline Plagioclase & $1.75 \%$ & \\
\hline Pyrite & $0.11 \%$ & \\
\hline Pyrophyllite & $0.04 \%$ & \\
\hline Quartz & $66.15 \%$ & \\
\hline Rutile & $0.27 \%$ & \\
\hline Siderite & $0.00 \%$ & \\
\hline Smectites & $9.16 \%$ & \\
\hline Zircon & $0.11 \%$ & \\
\hline
\end{tabular}

Figure A2. Cont. 

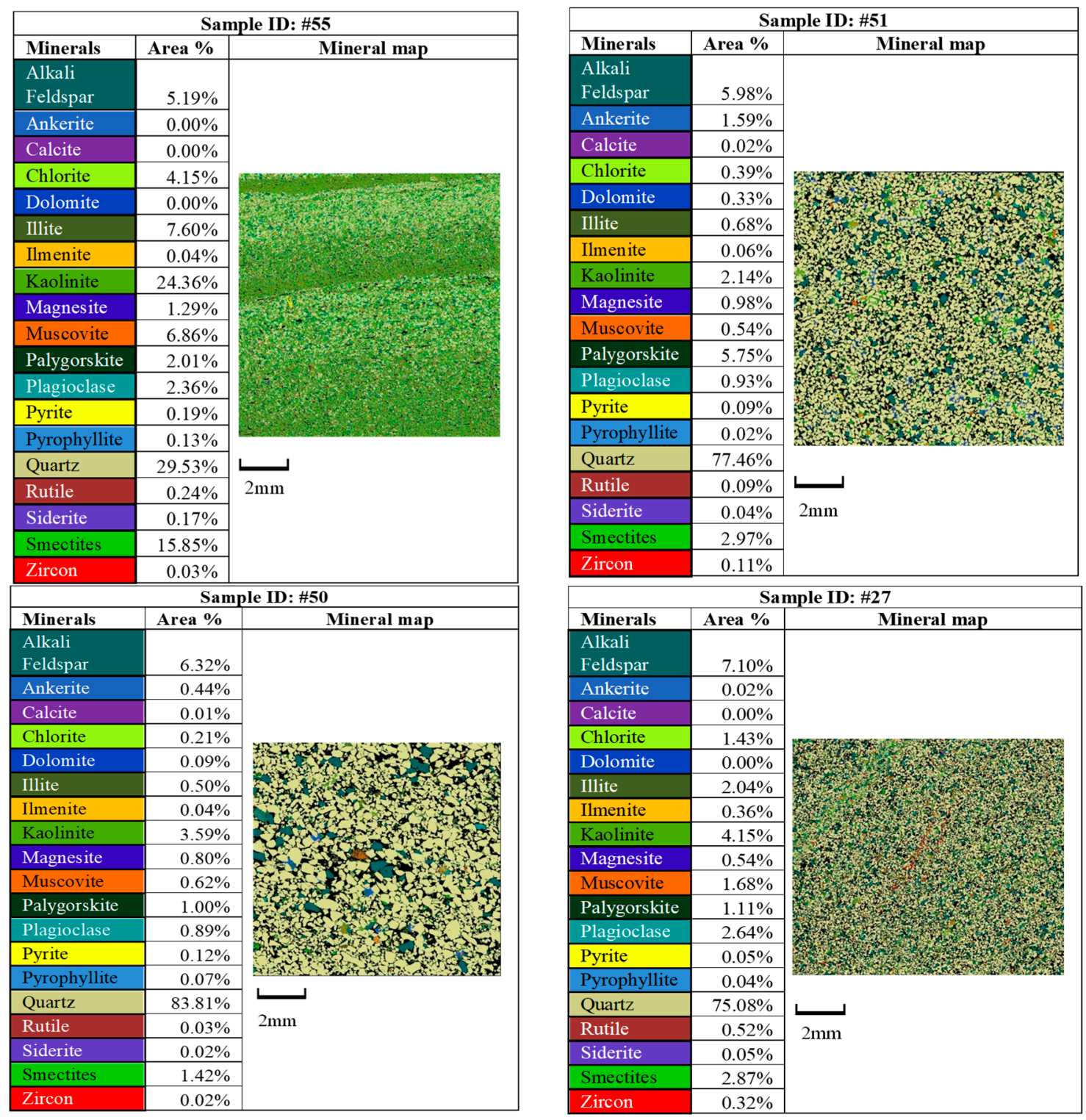

\begin{tabular}{|c|c|c|}
\hline \multicolumn{3}{|c|}{ Sample ID: \#25 } \\
\hline Minerals & Area \% & Mineral map \\
\hline $\begin{array}{l}\text { Alkali } \\
\text { Feldspar }\end{array}$ & $5.90 \%$ & \\
\hline Ankerite & $0.00 \%$ & \\
\hline Calcite & $0.00 \%$ & \\
\hline Chlorite & $1.66 \%$ & \\
\hline Dolomite & $0.00 \%$ & \\
\hline Illite & $3.09 \%$ & \\
\hline Ilmenite & $0.28 \%$ & \\
\hline Kaolinite & $10.17 \%$ & \\
\hline Magnesite & $0.58 \%$ & \\
\hline Muscovite & $1.47 \%$ & 80 \\
\hline Palygorskite & $4.32 \%$ & \\
\hline Plagioclase & $3.45 \%$ & \\
\hline Pyrite & $0.01 \%$ & \\
\hline Pyrophyllite & $0.10 \%$ & 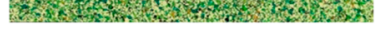 \\
\hline Quartz & $58.31 \%$ & \\
\hline Rutile & $0.38 \%$ & $2 \mathrm{~mm}$ \\
\hline Siderite & $0.03 \%$ & \\
\hline Smectites & $10.14 \%$ & \\
\hline Zircon & $0.10 \%$ & \\
\hline
\end{tabular}

\begin{tabular}{|c|c|c|}
\hline \multicolumn{3}{|c|}{ Sample ID: \#23 } \\
\hline Minerals & Area \% & Mineral map \\
\hline Alkali & & \multirow{20}{*}{ 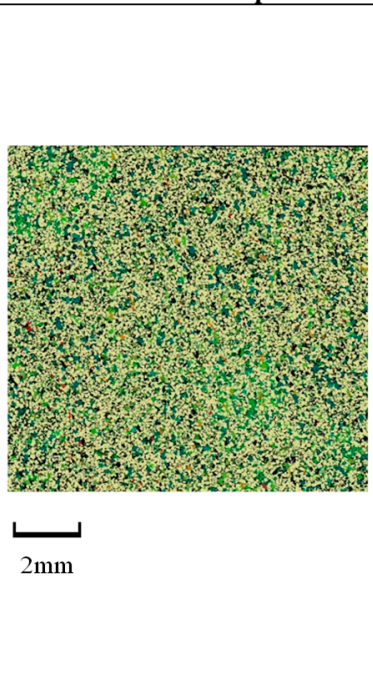 } \\
\hline Feldspar & $5.94 \%$ & \\
\hline Ankerite & $0.01 \%$ & \\
\hline Calcite & $0.00 \%$ & \\
\hline Chlorite & $0.87 \%$ & \\
\hline Dolomite & $0.00 \%$ & \\
\hline Illite & $1.74 \%$ & \\
\hline Ilmenite & $0.17 \%$ & \\
\hline Kaolinite & $3.52 \%$ & \\
\hline Magnesite & $0.43 \%$ & \\
\hline Muscovite & $0.92 \%$ & \\
\hline Palygorskite & $4.03 \%$ & \\
\hline Plagioclase & $2.47 \%$ & \\
\hline Pyrite & $0.04 \%$ & \\
\hline Pyrophyllite & $0.12 \%$ & \\
\hline Quartz & $74.18 \%$ & \\
\hline Rutile & $0.34 \%$ & \\
\hline Siderite & $0.01 \%$ & \\
\hline Smectites & $5.04 \%$ & \\
\hline Zircon & $0.17 \%$ & \\
\hline
\end{tabular}

Figure A2. Cont. 

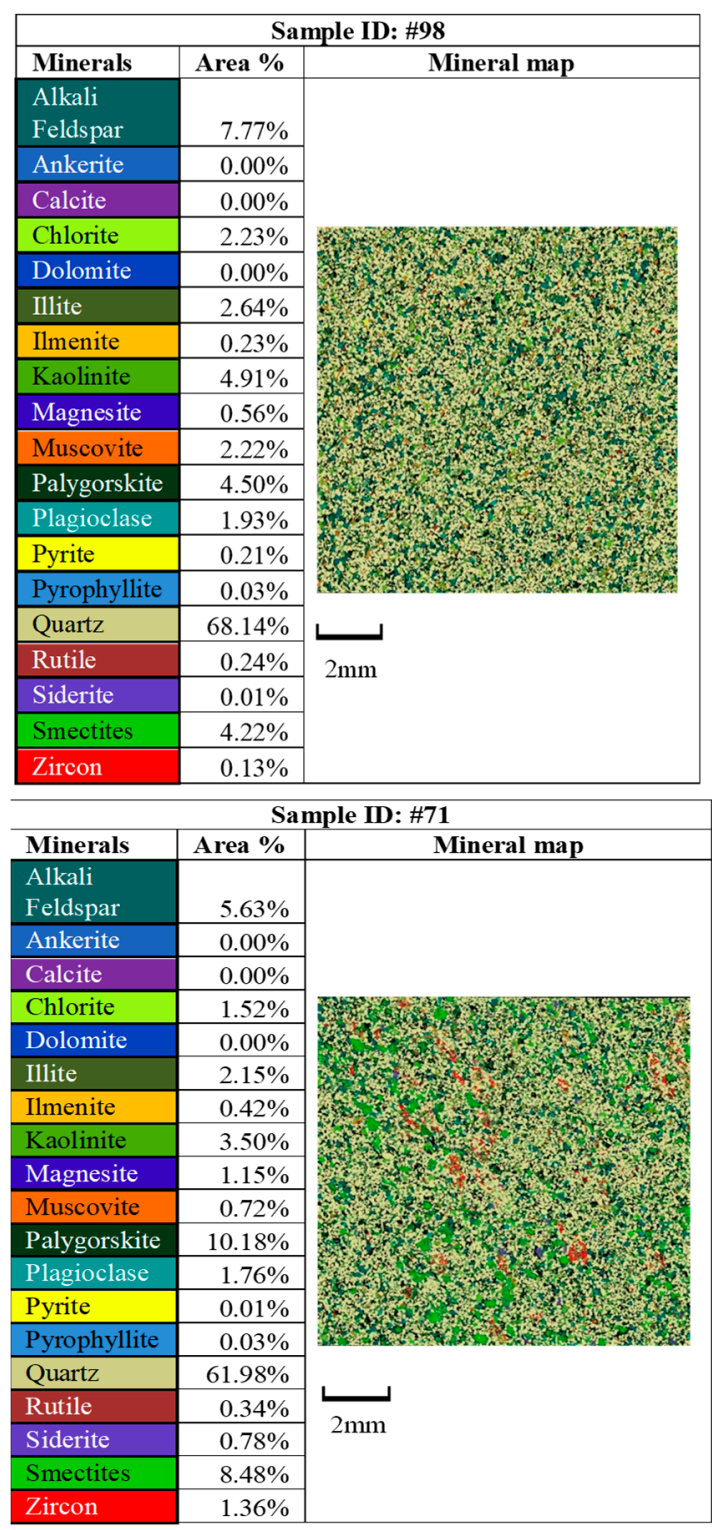

\begin{tabular}{|c|c|c|}
\hline \multicolumn{3}{|c|}{ Sample ID: \#67H } \\
\hline Minerals & Area \% & Mineral map \\
\hline $\begin{array}{l}\text { Alkali } \\
\text { Feldspar }\end{array}$ & $5.63 \%$ & \multirow{19}{*}{ 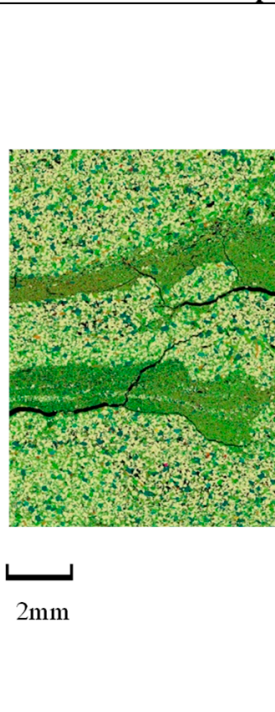 } \\
\hline Ankerite & $0.00 \%$ & \\
\hline Calcite & $0.00 \%$ & \\
\hline Chlorite & $5.25 \%$ & \\
\hline Dolomite & $0.00 \%$ & \\
\hline Illite & $8.12 \%$ & \\
\hline Ilmenite & $0.08 \%$ & \\
\hline Kaolinite & $12.82 \%$ & \\
\hline Magnesite & $1.15 \%$ & \\
\hline Muscovite & $3.82 \%$ & \\
\hline Palygorskite & $3.85 \%$ & \\
\hline Plagioclase & $1.98 \%$ & \\
\hline Pyrite & $0.21 \%$ & \\
\hline Pyrophyllite & $0.07 \%$ & \\
\hline Quartz & $45.15 \%$ & \\
\hline Rutile & $0.20 \%$ & \\
\hline Siderite & $0.18 \%$ & \\
\hline Smectites & $11.42 \%$ & \\
\hline Zircon & $0.03 \%$ & \\
\hline
\end{tabular}

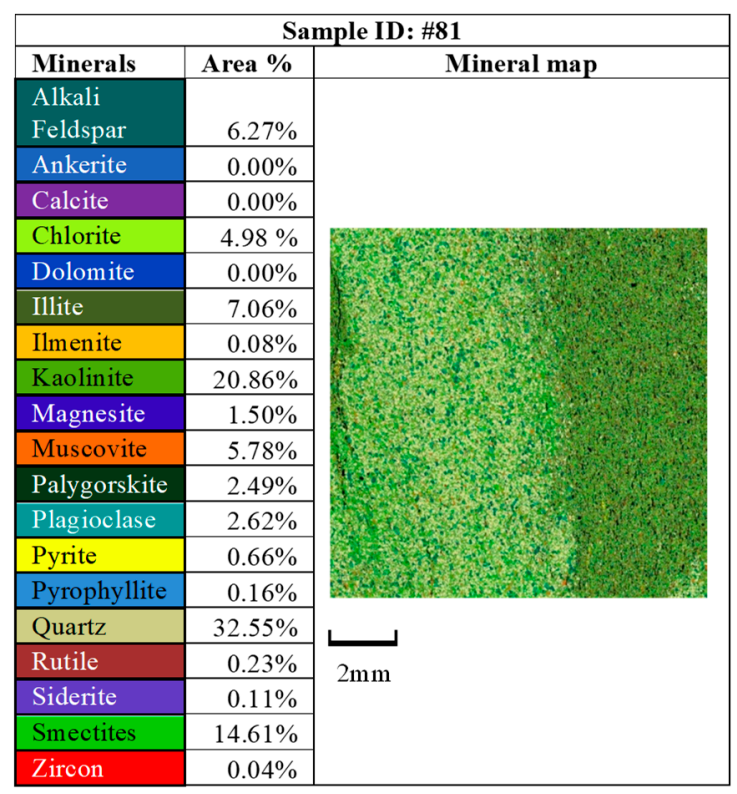

\begin{tabular}{|l|r|r|}
\hline \multicolumn{3}{|c|}{ Sample ID: \#69 } \\
\hline Minerals & \multicolumn{1}{|c|}{ Area \% } & Mineral map \\
\hline Alkali & & \\
Feldspar & $7.40 \%$ \\
\hline Ankerite & $0.00 \%$ \\
\hline Calcite & $0.00 \%$ \\
\hline Chlorite & $6.68 \%$ \\
\hline Dolomite & $0.00 \%$ & \\
\hline Illite & $8.01 \%$ & \\
\hline Ilmenite & $0.06 \%$ \\
\hline Kaolinite & $13.68 \%$ & \\
\hline Magnesite & $1.31 \%$ & \\
\hline Muscovite & $3.73 \%$ & \\
\hline Palygorskite & $3.39 \%$ \\
\hline Plagioclase & $3.28 \%$ \\
\hline Pyrite & $0.75 \%$ & \\
\hline Pyrophyllite & $0.08 \%$ & \\
\hline Quartz & $34.66 \%$ \\
\hline Rutile & $0.23 \%$ \\
\hline Siderite & $0.07 \%$ \\
\hline Smectites & $16.65 \%$ \\
\hline Zircon & $0.03 \%$ & \\
\hline \hline
\end{tabular}

\begin{tabular}{|l|r|r|}
\hline \multicolumn{2}{|c|}{ Sample ID: \#67V } \\
\hline Minerals & \multicolumn{1}{|c|}{ Area \% } & Mineral map \\
\hline Alkali & \\
Feldspar & $6.43 \%$ \\
\hline Ankerite & $0.00 \%$ \\
\hline Calcite & $0.00 \%$ \\
\hline Chlorite & $7.58 \%$ \\
\hline Dolomite & $0.00 \%$ \\
\hline Illite & $11.13 \%$ \\
\hline Ilmenite & $0.08 \%$ \\
\hline Kaolinite & $12.17 \%$ \\
\hline Magnesite & $1.88 \%$ \\
\hline Muscovite & $7.15 \%$ \\
\hline Palygorskite & $3.78 \%$ \\
\hline Plagioclase & $2.26 \%$ \\
\hline Pyrite & $0.27 \%$ \\
\hline Pyrophyllite & $0.04 \%$ \\
\hline Quartz & $30.50 \%$ \\
\hline Rutile & $0.25 \%$ \\
\hline Siderite & $0.41 \%$ \\
\hline Smectites & $15.99 \%$ \\
\hline Zircon & $0.07 \%$ & \\
\hline
\end{tabular}




\begin{tabular}{|c|c|c|}
\hline \multicolumn{3}{|c|}{ Sample ID: \#66 } \\
\hline Minerals & Area \% & Mineral map \\
\hline $\begin{array}{l}\text { Alkali } \\
\text { Feldspar }\end{array}$ & $7.75 \%$ & \multirow{19}{*}{ 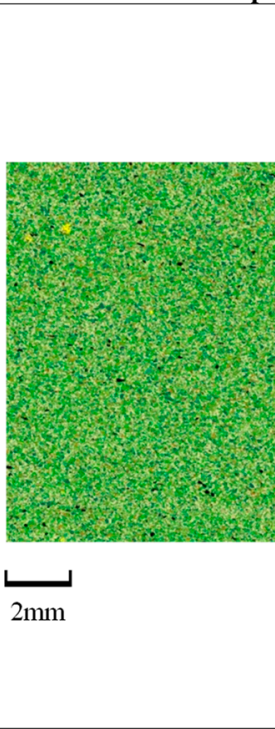 } \\
\hline Ankerite & $0.00 \%$ & \\
\hline Calcite & $0.00 \%$ & \\
\hline Chlorite & $6.39 \%$ & \\
\hline Dolomite & $0.00 \%$ & \\
\hline Illite & $8.81 \%$ & \\
\hline Ilmenite & $0.06 \%$ & \\
\hline Kaolinite & $14.99 \%$ & \\
\hline Magnesite & $0.95 \%$ & \\
\hline Muscovite & $3.31 \%$ & \\
\hline Palygorskite & $2.56 \%$ & \\
\hline Plagioclase & $3.27 \%$ & \\
\hline Pyrite & $0.16 \%$ & \\
\hline$\overline{\text { Pyrophyllite }}$ & $0.10 \%$ & \\
\hline Quartz & $34.42 \%$ & \\
\hline Rutile & $0.23 \%$ & \\
\hline Siderite & $0.08 \%$ & \\
\hline Smectites & $16.88 \%$ & \\
\hline Zircon & $0.02 \%$ & \\
\hline
\end{tabular}

\begin{tabular}{|l|r|r|}
\hline \multicolumn{3}{|c|}{ Sample ID: \#64 } \\
\hline Minerals & Area $\%$ & Mineral map \\
\hline Alkali & \\
Feldspar & $6.86 \%$ \\
\hline Ankerite & $0.00 \%$ \\
\hline Calcite & $0.00 \%$ \\
\hline Chlorite & $2.11 \%$ \\
\hline Dolomite & $0.00 \%$ \\
\hline Illite & $3.15 \%$ \\
\hline Ilmenite & $0.14 \%$ \\
\hline Kaolinite & $4.84 \%$ \\
\hline Magnesite & $0.31 \%$ \\
\hline Muscovite & $1.61 \%$ \\
\hline Palygorskite & $3.00 \%$ \\
\hline Plagioclase & $2.26 \%$ \\
\hline Pyrite & $0.09 \%$ & \\
\hline Pyrophyllite & $0.04 \%$ \\
\hline Quartz & $70.74 \%$ \\
\hline Rutile & $0.24 \%$ \\
\hline Siderite & $0.01 \%$ \\
\hline Smectites & $4.55 \%$ \\
\hline Zircon & $0.04 \%$ & \\
\hline
\end{tabular}

Figure A2. Cont. 


\section{Appendix D}
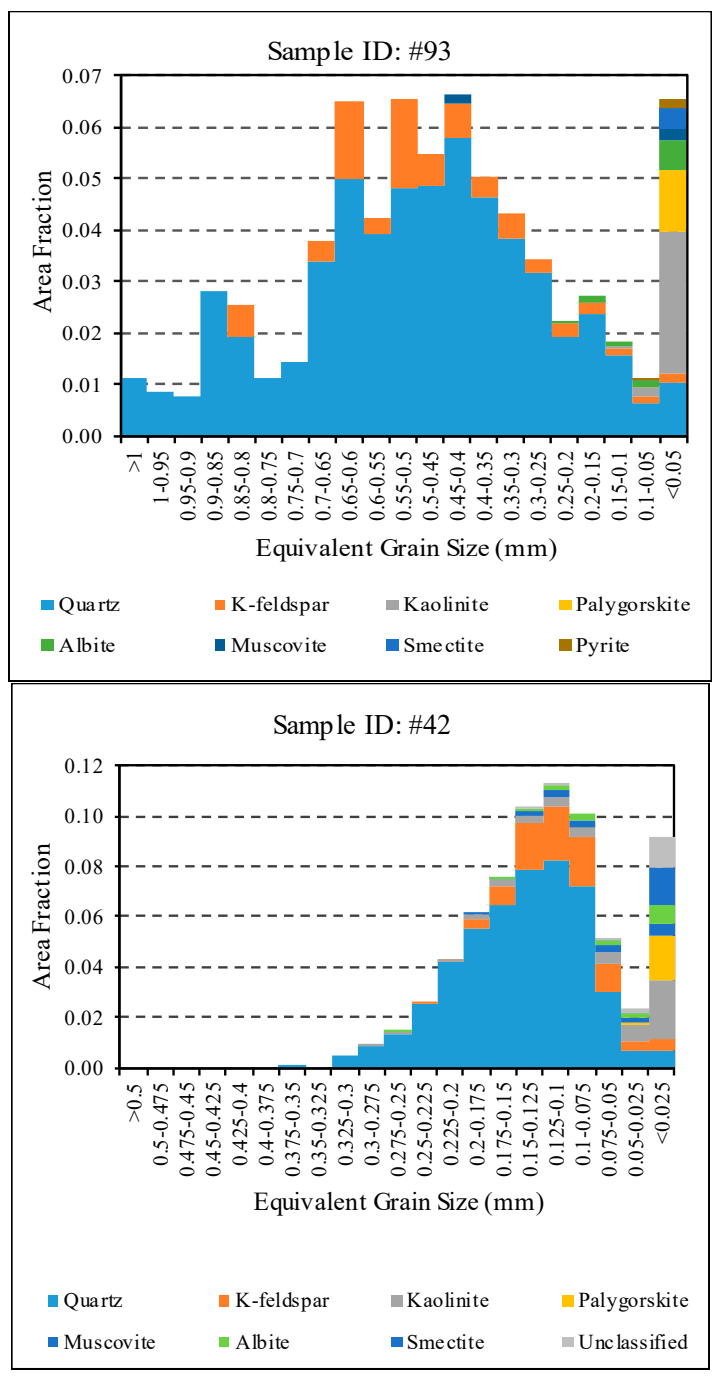
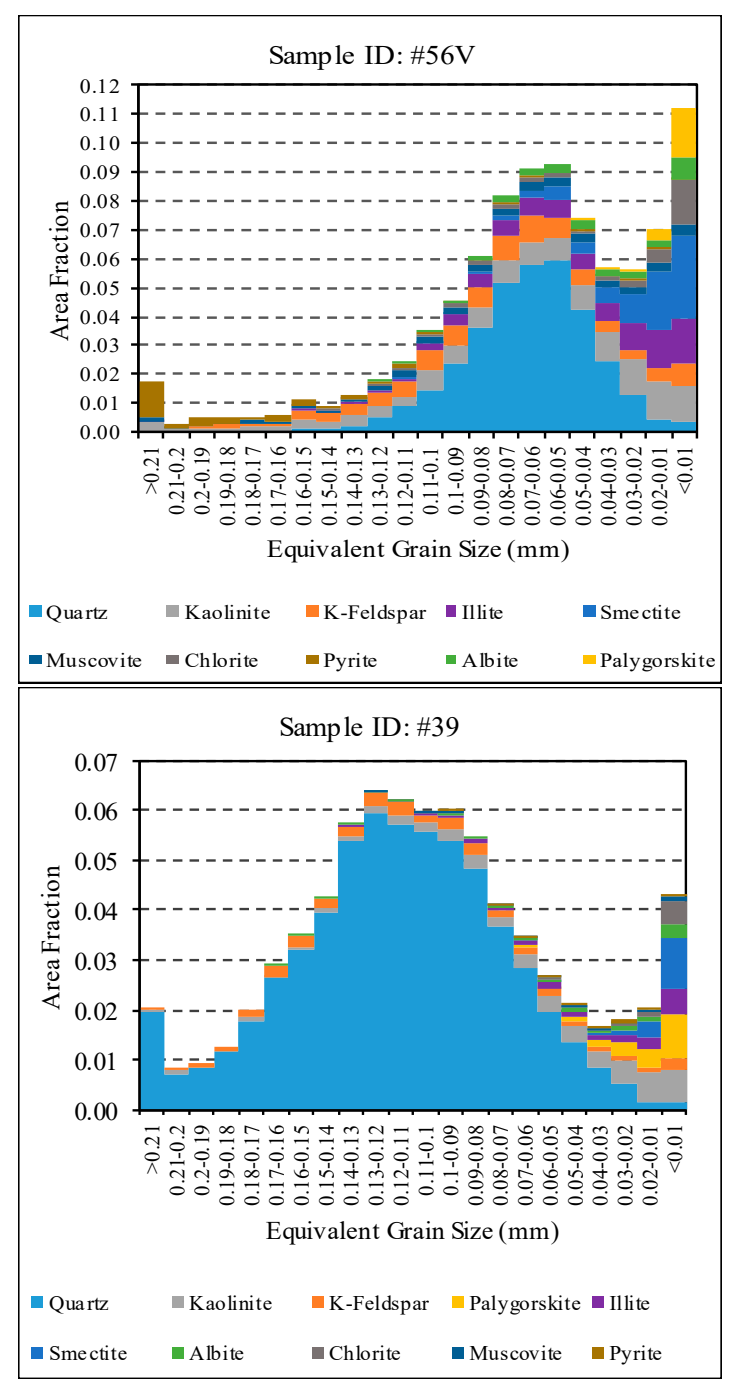

Figure A3. Cont. 

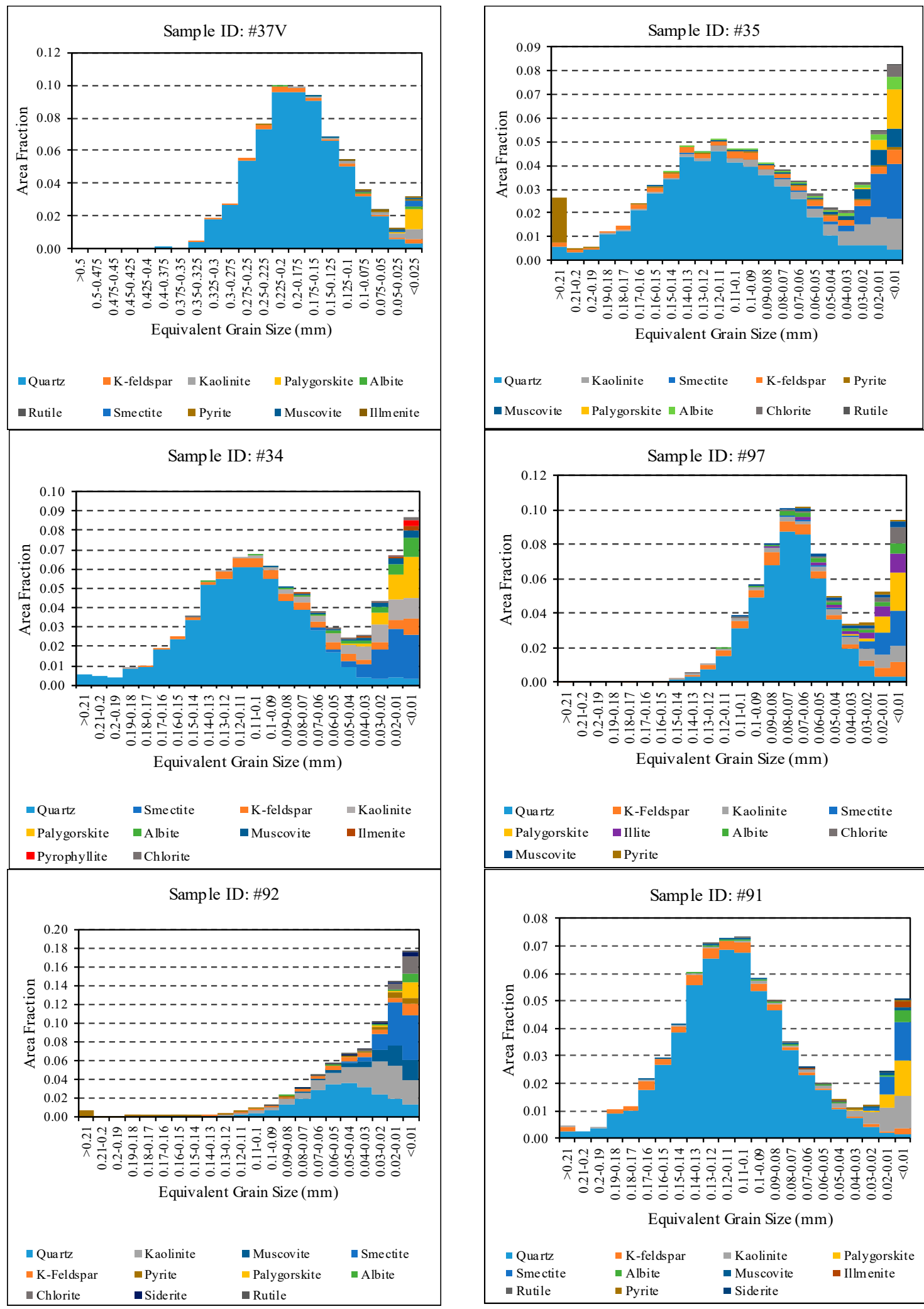

\begin{tabular}{llll}
$\square$ Quartz & $\square$ K-Feldspar & $\square$ Kaolinite & Smectite \\
$\square$ Palygorskite & $\square$ Illite & Albite & $\square$ Chlorite \\
$\square$ Muscovite & $\square$ Pyrite & & \\
\hline
\end{tabular}

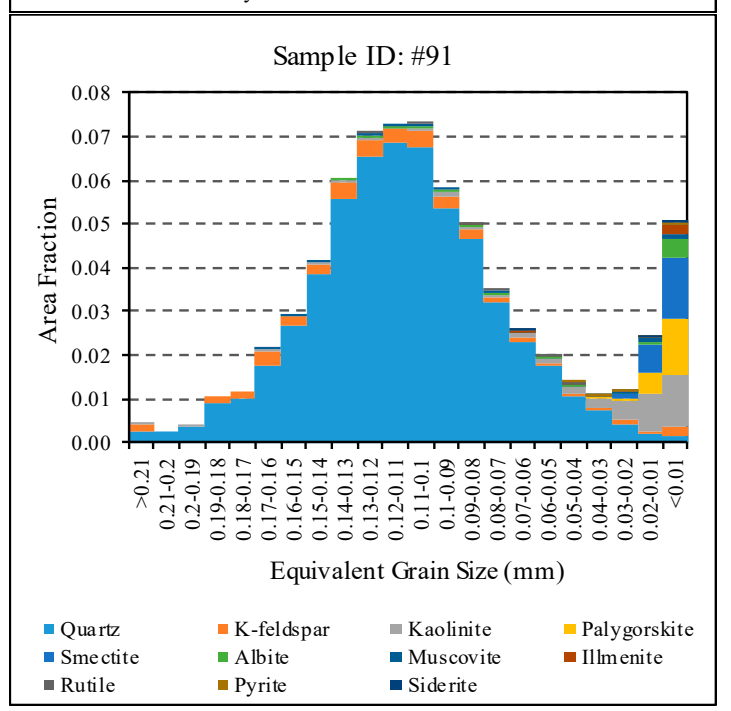

Figure A3. Cont. 

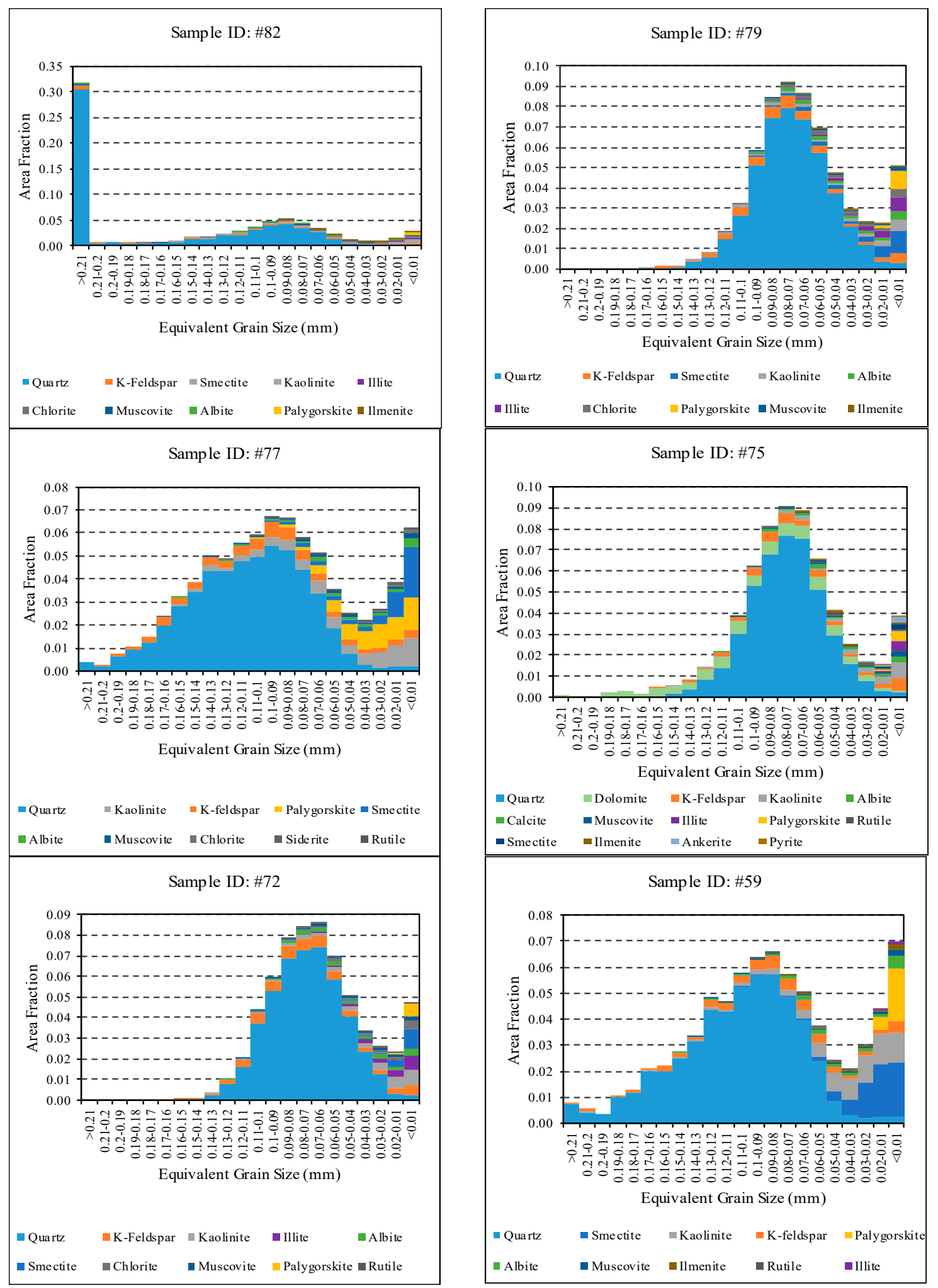

Figure A3. Cont. 


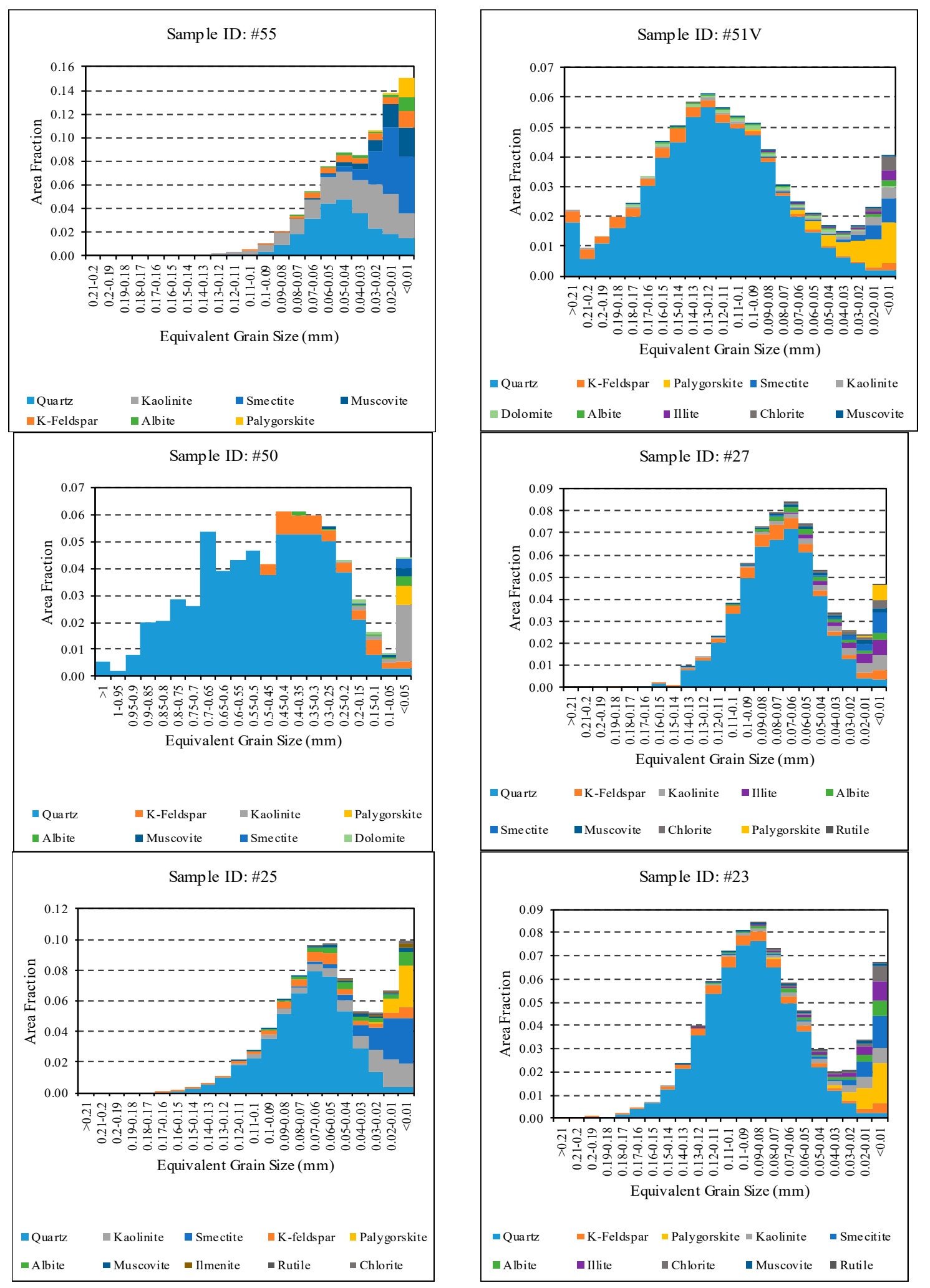

Figure A3. Cont. 


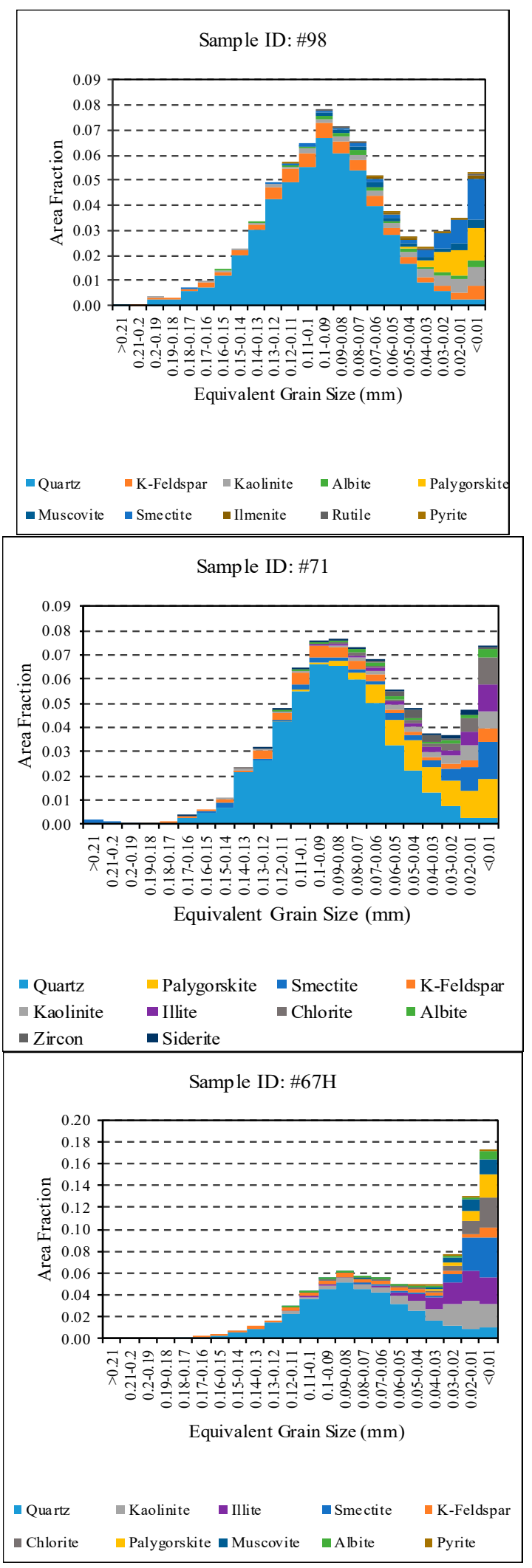

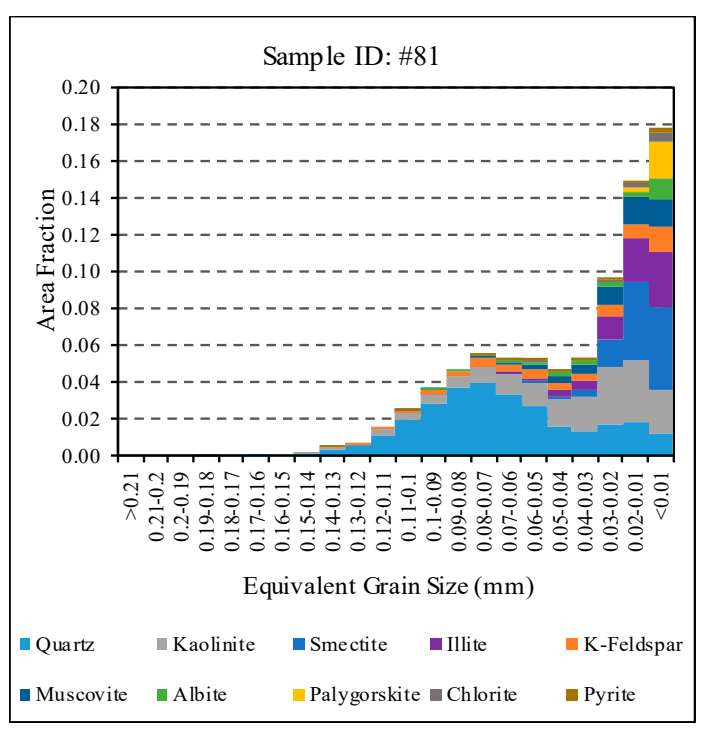

- Muscovite Albite Pyrite
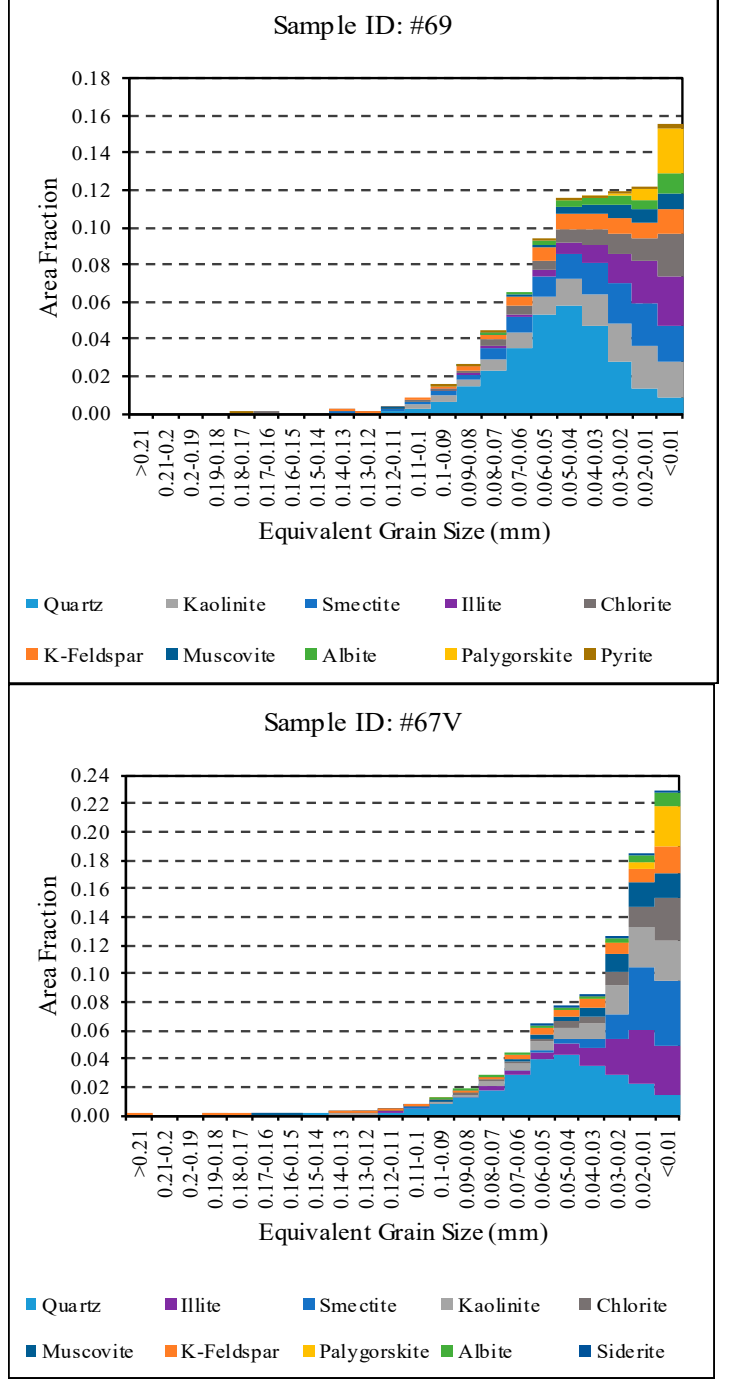

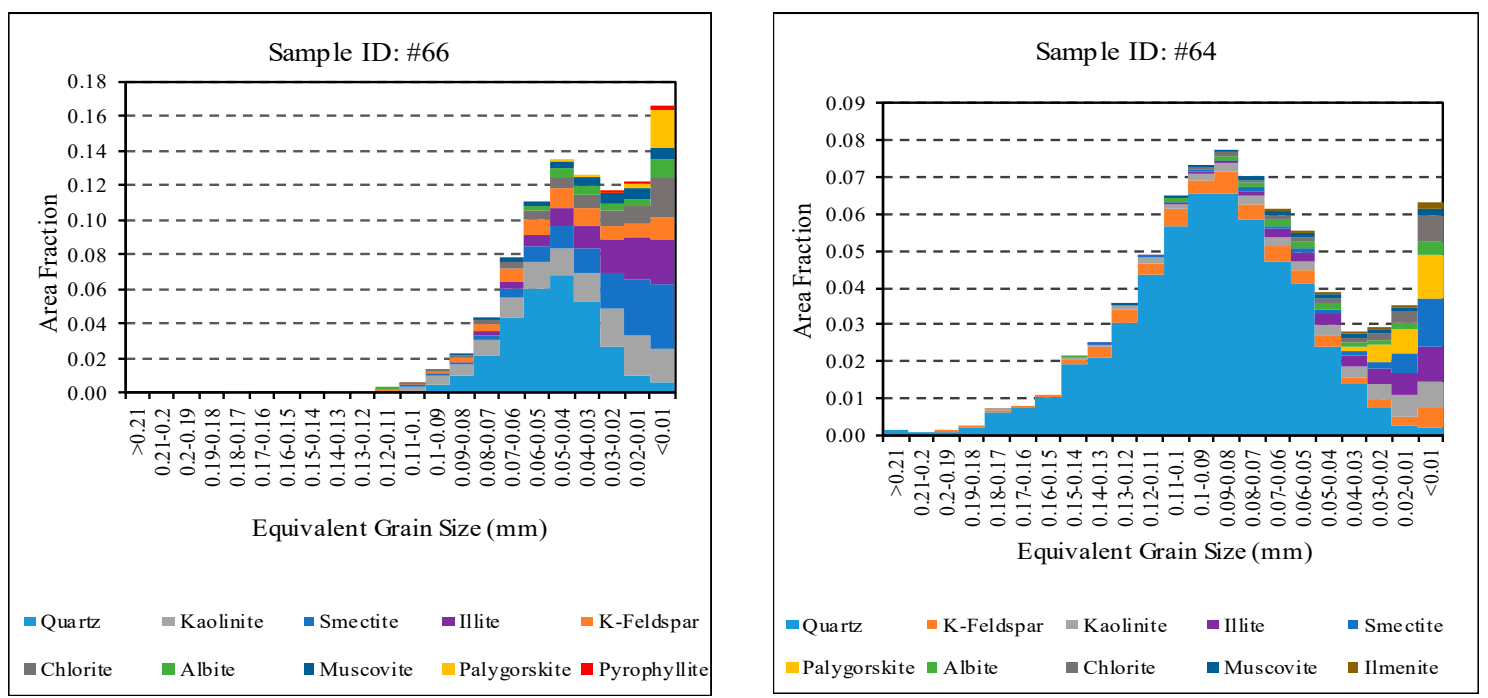

Figure A3. The following section presents the results of the grain size analysis of the 30 samples from CRC-3. The analysis is done in terms of area fraction covered on the minerals maps as a function of the equivalent grain size of different mineral phases.

\section{References}

1. Steefel, C.I.; DePaolo, D.J.; Lichtner, P.C. Reactive transport modeling: An essential tool and a new research approach for the Earth sciences. Earth Planet. Sci. Lett. 2005, 240, 539-558. [CrossRef]

2. Doyen, P. Seismic Reservoir Characterization: An Earth Modelling Perspective; EAGE publications: Houten, The Netherlands, 2007; Volume 2.

3. Ringrose, P.; Bentley, M. Reservoir model types. In Reservoir Model Design; Springer: Dordrecht, The Netherlands, 2015; pp. 173-231.

4. Gershenzon, N.I.; Ritzi, R.W.; Dominic, D.F.; Mehnert, E.; Okwen, R.T. Capillary trapping of $\mathrm{CO}_{2}$ in heterogeneous reservoirs during the injection period. Int. J. Greenh. Gas. Con. 2017, 59, 13-23. [CrossRef]

5. Trevisan, L.; Krishnamurthy, P.G.; Meckel, T.A. Impact of 3D capillary heterogeneity and bedform architecture at the sub-meter scale on $\mathrm{CO}_{2}$ saturation for buoyant flow in clastic aquifers. Int. J. Greenh. Gas. Con. 2017, 56, 237-249. [CrossRef]

6. Miall, A.D. Facies Models Stratigraphy: A Modern Synthesis; Springer: Berlin/Heidelberg, Germany, 2016; pp. 161-214.

7. Ennis-King, J.; Bradshaw, J.; Gibson-Poole, C.; Hennig, A.; Lang, S.; Paterson, L.; Root, R.; Sayers, J.; Spencer, L.; Streit, J. Long-term numerical simulation of a portfolio of possible sites for geological storage of carbon dioxide in Australia. Greenh. Gas Con. Technol. 7 2005, 1, 711-719.

8. Liang, C.; Cao, Y.; Liu, K.; Jiang, Z.; Wu, J.; Hao, F. Diagenetic variation at the lamina scale in lacustrine organic-rich shales: Implications for hydrocarbon migration and accumulation. Geochim. Cosmochim. Acta 2018, 229, 112-128. [CrossRef]

9. Ringrose, P.S.; Sorbie, K.S.; Corbett, P.W.M.; Jensen, J.L. Immiscible flow behaviour in laminated and cross-bedded sandstones. J. Pet. Sci. Eng. 1993, 9, 103-124. [CrossRef]

10. Yang, L.; Xu, T.; Yang, B.; Tian, H.; Lei, H. Effects of mineral composition and heterogeneity on the reservoir quality evolution with $\mathrm{CO}_{2}$ intrusion. Geochem. Geophy. Geosy. 2014, 15, 605-618. [CrossRef]

11. Flett, M.; Gurton, R.; Weir, G. Heterogeneous saline formations for carbon dioxide disposal: Impact of varying heterogeneity on containment and trapping. J. Pet. Sci. Eng. 2007, 57, 106-118. [CrossRef]

12. Mikes, D.; Barzandji, O.H.M.; Bruining, J.; Geel, C.R. Upscaling of small-scale heterogeneities to flow units for reservoir modelling. Mar. Pet. Geol. 2006, 23, 931-942. [CrossRef]

13. Wen, H.; Li, L. An upscaled rate law for magnesite dissolution in heterogeneous porous media. Geochim. Cosmochim. Acta 2017, 210, 289-305. [CrossRef]

14. Cooperative Research Centre for Greenhouse Gas Technologies. Available online: http://www.co2crc.com. au/otway-research-facility-2/ (accessed on 17 June 2019). 
15. Boyd, G.A.; Gallagher, S.J. The sedimentology and palaeoenvironments of the Late Cretaceous Sherbrook Group in the Otway Basin. East. Aust. Basins Symp. 2001, 475-484.

16. Dance, T.; Arnot, M.; Bunch, M.; Hortle, A.; Lawrence, M.; Ennis-King, J. Geocharacterisation and Static Modelling of the Lower Paaratte Formation; CO2CRC Otway Project Stage 2; Cooperative Research Centre for Greenhouse Gas Technologies: Canberra, Australia, 2012; CO2CRC Publication Number RPT12-3481.

17. Geary, G.C.; Constantine, A.E.; Reid, I.S.A. New Perspectives on Structural Style and Petroleum Prospectivity, Offshore Eastern Otway Basin; Petroleum Exploration Society of Australia (PESA): Adelaide, Australia, 2001.

18. Geary, G.C.; Reid, I.S.A. Geology and Prospectivity of the Offshore Eastern Otway Basin, Victoria - for the 1998 Acreage Release; Department of Natural Resources and Environment: Palmerston, Australia, 1998.

19. Lawrence, M.J.F.; Arnot, M.; Browne, G.H.; Bunch, M.; Dance, T. Geological Interpretation of Core and Wireline Data from Otway Project Wells CRC-1 and CRC-2; CO2CRC Publication Number RPT12-3481; Cooperative Research Centre for Greenhouse Gas Technologies: Canberra, Australia, 2013.

20. Daniel, R. Containment/Injectivity Results from MICP Analysis for Seals, Intraformational Barriers and Reservoir Samples, CRC-2, Otway Basin; CO2CRC Publication Number: TBN 12-3830; Cooperative Research Centre for Greenhouse Gas Technologies: Melbourne, Australia, 2012.

21. Daniel, R.F.; Menacherry, S.; Bunch, M. Characterisation of Dolomitic Intraformational Barriers, CRC-2B Injection Interval, Paaratte Formation; CO2CRC Publication Number: RPT12-3532; Cooperative Research Centre for Greenhouse Gas Technologies: Melbourne, Australia, 2012.

22. Dance, T. Characterisation of the Late Cretaceous Paaratte Formation, a heterogeneous saline aquifer, for an Australian $\mathrm{CO}_{2}$ Storage Project. J. Pet. Geol. 2018. (submitted).

23. Dance, T. Assessment and geological characterisation of the $\mathrm{CO} 2 \mathrm{CRC}$ Otway Project $\mathrm{CO}_{2}$ storage demonstration site: From prefeasibility to injection. Mar. Pet. Geol. 2013, 46, 251-269. [CrossRef]

24. Combinable Magnetic Resonance Report; Schlumberger and CO2CRC Limited: Perth, Australia, (unpublished).

25. Moore, A.M.G.; Stagg, H.M.J.; Norvick, M.S. Deep-water Otway Basin: A new assessment of the tectonics and hydrocarbon prospectivity. APPEA J. 2000, 40, 66-85. [CrossRef]

26. Exon, N.F.; Lee, C.S. Seabed sampling off southeast Australia. BMR Res. Newsl. 1987, $2-4$.

27. Miyazaki, S.; Lavering, I.H.; Stephenson, A.E.; Pain, L. Otway Basin, South Australia, Victoria and Tasmania. Aust. Bur. Miner. Resour. Geol. Geophys. Pet. Accumul. Rep. 1990, 6, 62-66.

28. Robertson, C.S.; Cronk, D.K.; Mayne, S.J.; Townsend, D.G. A review of petroleum exploration and prospects in the Otway Basin region. Canberra: Geosci. Aust. 1978, 49.

29. Stacey, A.; Mitchell, C.; Nayak, G.; Struckmeyer, H.; Morse, M.; Totterdell, J.; Gibson, G. Geology and petroleum prospectivity of the deepwater Otway and Sorell basins: new insights from an integrated regional study. APPEA J. 2011, 51, 692. [CrossRef]

30. Holford, S.; Hillis, R.; Duddy, I.; Green, P.; Stoker, M.; Tuitt, A.; Backé, G.; Tassone, D.; MacDonald, J. Cenozoic post-breakup compressional deformation and exhumation of the southern Australian margin. APPEA J. 2011, 51, 613-638. [CrossRef]

31. Krassay, A.A.; Cathro, D.L.; Ryan, D.J.; Boult, P.J.; Johns, D.R.; Lang, S.C. A Regional Tectonostratigraphic Framework for the Otway Basin; Petroleum Exploration Society of Australia (PESA): Adelaide, Australia, 2004; pp. 97-116.

32. Norvick, M.S. Plate Tectonic Reconstructions of Australia's Southern Margins; Geoscience Australia: Canberra, Australia, 2005.

33. Willcox, J.B.; Stagg, H.M.J. Australia's southern margin: a product of oblique extension. Tectonophysics 1990, 173, 269-281. [CrossRef]

34. Geoscience Australia. Available online: www.ga.gov.au/scientific-topics/energy/province-sedimentarybasin-geology/petroleum/offshore-southern-australia/otway (accessed on 11 January 2019).

35. Cande, S.C.; Mutter, J.C. A revised identification of the oldest sea-floor spreading anomalies between Australia and Antarctica. Earth Planet. Sci. Lett. 1982, 58, 151-160. [CrossRef]

36. Woollands, M.A.; Wong, D. Petroleum Atlas of Victoria, Australia; Department of Natural Resources and Environment: Palmerston, Australia, 2001.

37. Morton, J.G.G.; Hill, A.J.; Parker, G.; Tabassi, A. Towards a unified stratigraphy for the Otway Basin. In Proceedings of the NGMA/Petroleum Exploration Society of Australia Otway Basin Symposium, Melbourne, Australia, 20 April 1994. 
38. Buffin, A.J. Waarre sandstone development within the Port Campbell Embayment. APPEA J. 1989, 29, 299-311. [CrossRef]

39. Hawkins, P.J.; Dellenbach, J. A Review of the Otway Basin; Reynolds, M.A., Ed.; Bureau of Mineral Resources: Canberra, Australia, 1971; pp. 7-22.

40. Morgan, R.P. Palynology review of selected oil drilling. Otway Basin, South Australia, for Ultramar Australia. Aust. Morgan Palaeo Assoc. 1985. Unpublished.

41. Morton, J.G.G. Revisions to stratigraphic nomenclature of the Otway Basin, South Australia. In Quarterly Geological Notes/Issued by the Geological Survey of South Australia; Parkside: Auckland, New Zealand, 1990.

42. White, M.R. Micropalaeontological analysis of 26 petroleum wells in the Gambier Basin, South Australia. South Aust. Dep. Mines Energy Rep. Book 1995, 95, 6.

43. O'Brien, G.W.; Thomas, J.H. A Technical Assessment of the Yet-to-Find Hydrocarbon Resource Inventory, Offshore $\mathcal{E}$ Onshore Otway Basin, Victoria, Australia; Department of Primary Industries: New South Wales, Australia, 2007.

44. Dance, T. Personal Communication; CSIRO: Canberra, Australia, 2017.

45. Knackstedt, M.; Saadatfarm, M.; Herring, A.; Turner, M.; Sok, R.; Deakin, L.; Knuefing, L.; Eric Oren, P.; Ruspini, L. Multiphase flooding dynamics of Otway core. Phase 1. Cooperative Research Centre for Greenhouse Gas Technologies, Melbourne, Australia, CO2CRC Report No: RPT18-5867; CO2CRC Limited: Carlton, Australia, 2018.

46. Kaldi, J.; Daniel, R.; Tenthorey, E.; Michael, K.; Schacht, U.; Nicol, A.; Underchultz, J.; Backe, G. Caprock Systems for $\mathrm{CO}_{2}$ Geological Storage; Report No.: 2011/01; IEAGHG: Cheltenham, UK, 2011.

47. Higgs, K.E.; Haese, R.R.; Golding, S.D.; Schacht, U.; Watson, M.N. The Pretty Hill Formation as a natural analogue for $\mathrm{CO}_{2}$ storage: an investigation of mineralogical and isotopic changes associated with sandstones exposed to low, intermediate and high $\mathrm{CO}_{2}$ concentrations over geological time. Chem. Geol. 2015, 399, 36-64. [CrossRef]

48. Ayling, B.; Rose, P.; Petty, S.; Zemach, E.; Drakos, P. QEMSCAN (Quantitative evaluation of minerals by scanning electron microscopy): Capability and application to fracture characterization in geothermal systems. In Proceedings of the 37th Workshop on Geothermal Reservoir Engineering, Stanford, CA, USA, 30 January-1 February 2012.

49. Schodlok, M.C.; Whitbourn, L.; Huntington, J.; Mason, P.; Green, A.; Berman, M.; Coward, D.; Connor, P.; Wright, W.; Jolivet, M. HyLogger-3, a visible to shortwave and thermal infrared reflectance spectrometer system for drill core logging: functional description. Aust. J. Earth Sci. 2016, 63, 929-940.

50. Huntington, J.; Whitbourn, L.; Mason, P.; Berman, M.; Schodlok, M.C. HyLogging-Voluminous industrial-scale reflectance spectroscopy of the Earth's subsurface. In Proceedings of the ASD and IEEE GRS; Art, Science and Applications of Reflectance Spectroscopy Symposium, Boulder, CO, USA, 23-25 February 2010.

51. Cudahy, T.J.; Hewson, R.D.; Caccetta, M.; Roache, A.; Whitbourn, L.B.; Connor, P.; Coward, D.; Mason, P.; Yang, K.; Huntington, J.F. Drill core Logging of plagioclase feldspar composition and other minerals associated with Archaean gold mineralisation at Kambalda, Western Australia using a bidirectional thermal infrared reflectance system. In Remote Sensing and Spectral Geology; Society of Economic Geologists: Littleton, CO, USA, 2009; pp. 223-235.

52. Haese, R.R.; Jiang, G.; Ooi, S.; Black, J.R. Enhanced reservoir characterization using hyperspectral core logging. J. Sediment. Res. 2019, 89, 187-198. [CrossRef]

53. Schlumberger. Available online: www.glossary.oilfield.slb.com/en/Terms/e/elemental_capture_spectroscopy. aspx (accessed on 6 March 2019).

54. Kansas Geological Survey. Available online: http://www.kgs.ku.edu/stratigraphic/KIMELEON/history.html (accessed on 11 January 2019).

55. Collins, D.R.; Doveton, J.H. Color images of Kansas subsurface geology from well logs. Comput. Geosci. 1986, 12, 519-526. [CrossRef]

(C) 2019 by the authors. Licensee MDPI, Basel, Switzerland. This article is an open access article distributed under the terms and conditions of the Creative Commons Attribution (CC BY) license (http://creativecommons.org/licenses/by/4.0/). 